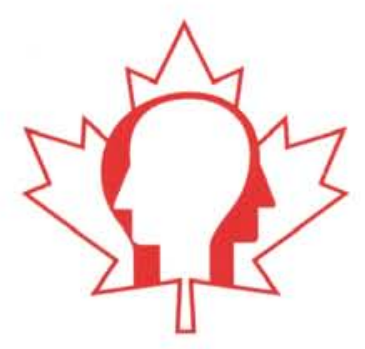

THE CANADIAN JOURNAL OF

Neurological Sciences

LE JOURNAL CANADIEN DES

Sciences Neurologiques

AN INTERNATIONAL JOURNAL / UN JOURNAL INTERNATIONAL

EDITORIAIS

187 Oligodendrogliomas: 'The Achilles' Heel of Malignant Gliomas

Peter A. Forsyth and Douglas A. Stewart

189 Do Case Series have a Role in an Evidence-Based Medical Culture?

Vera Bril

REVIEW ARTICLES

191 Invited Review: Status of Current Clinical Trials in Diabetic Polyneuropathy Vera Bril

199 Progress in Clinical Neurosciences:

Charcot-Marie-Tooth Disease and Related Inherited Peripheral Neuropathies

Timothy J. Benstead and Ian A. Grant

ORIGINAL ARTICLES

215 PCV for Oligodendroglial Tumors: In Search of Prognostic Factors for Response and Survival David Fortin, David. R. Macdonald, Larry Stitt, J. Gregory Cairncross

224 Methylprednisolone May Improve Lumbosacral Radiculoplexus Neuropathy P. James B. Dyck, Jane E. Norell, and Peter James Dyck

228 Neurocognitive Symptoms and Impairment in an HIV Community Clinic D.H. Kim, D.L. Jewison, G.R. Milner, S.B. Rourke, MJ. Gill, C. Power

232 Methodology for the Canadian Activase for Stroke Effectiveness Study (CASES) Michael D. Hill. Alastair M. Buchan and the CASES Investigators

239 Prospective Analysis of Relationships of Outcome Measures for Ulnar Neuropathy at the Elbow Rajiv Midha, Jason Noble, Vivek Patel, Peter H. Ho, Catherine A. Munro, John Paul Szalai

245 Identification of the Temporal Components of Seizure Onset in the Scalp FEG Nora S. O'Neill, Manouchehir Javidan. Zoltan J. Koles

NEUROIMAGING HIGHLIGHT

254 Shah-Naz Hayat Khan, Suzanne Hattingh, Robert William Griebel CASE REPORTS

37th CANADIAN CONGRESS OF

NEUROLOGICAL SCIENCES

June $18-22,2002$

Vancouver. British Columbia
256 Endovascular Treatment of a Lenticulostriate Artery Aneurysm with N-butyl Cyanoacrylate Ramiro Larrazabal, David Pelz. J. Max Findlay

260 Encephalopathy with Staphylococcal Endocarditis: Multiple Neuropathological Findings S.G. Weeks, C. Silva, R.N. Awer, C.J. Doig, MJ., Gill, C. Power

265 Spontaneous Internal Carotid Artery Dissection with Lower Cranial Nerve Palsy N. Guy, D. Deffond, J. Gabrillargues, N. Carriere, G. Dordain, P. Clavelou

\section{IN MEMORIAM}

270. Mary Anne Lee

Douglas Zochodne
The official Journal of: The Canadian Neurological Society, The Canadian Neurosurgical Society, The Canadian Society of Clinical Neurophysiologists, The Canadian Association of Child Neurology 


\section{Rebif. Dose-dependent Efficacy in
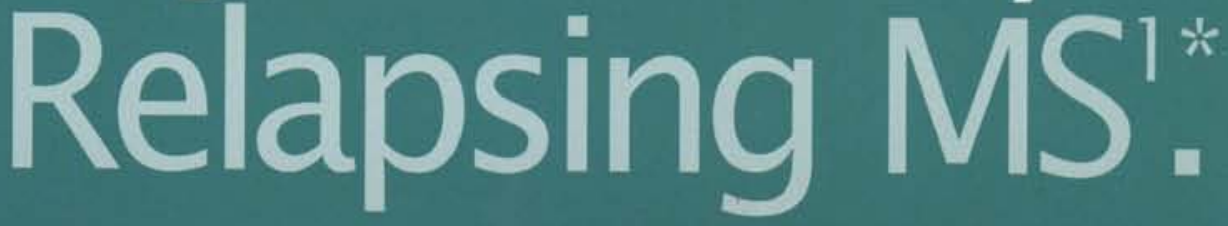
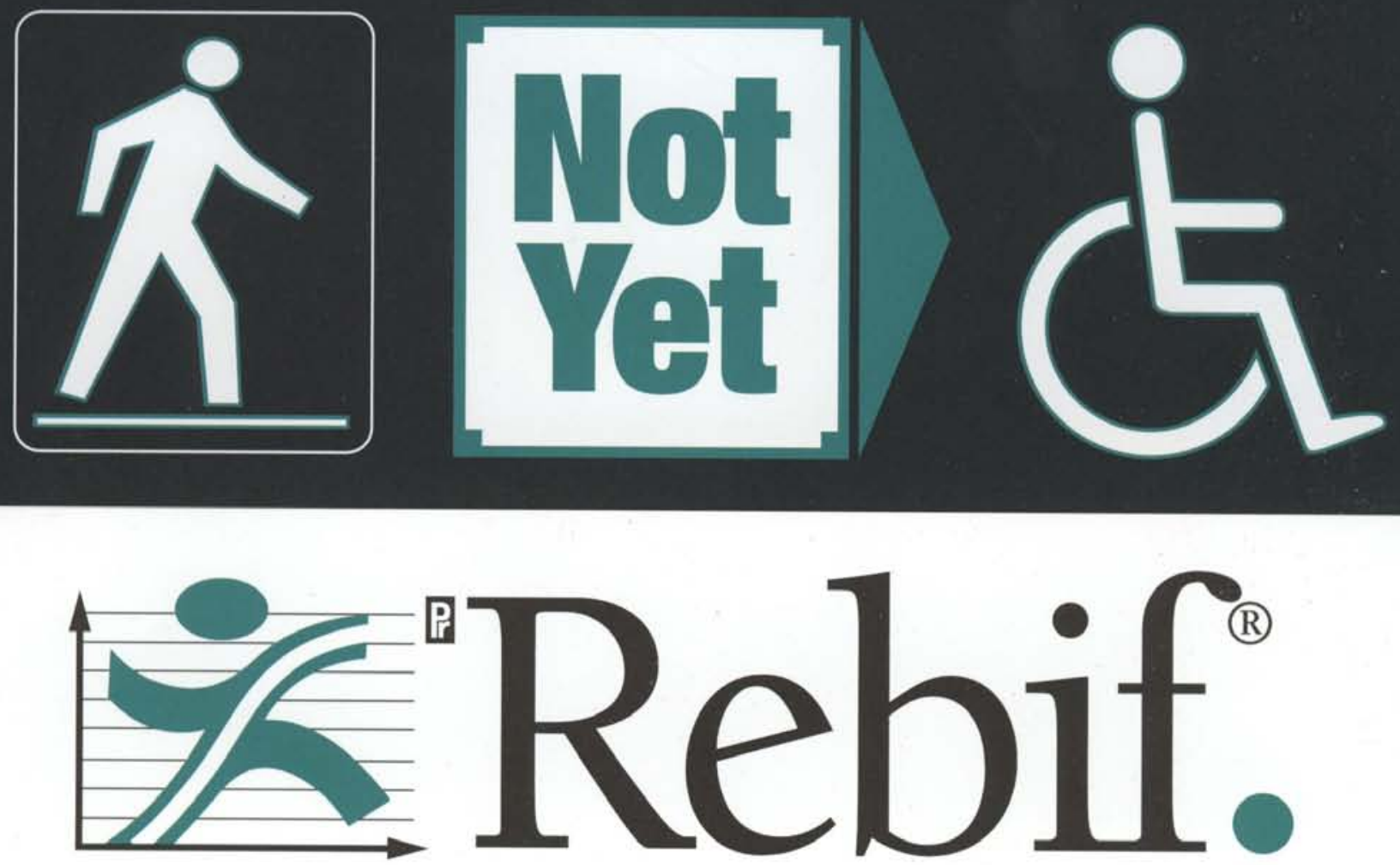

I $\mathrm{n}$ t e r f e r o $\mathrm{n}$ b e t a - 1 a

ready-to-use

pre-filled

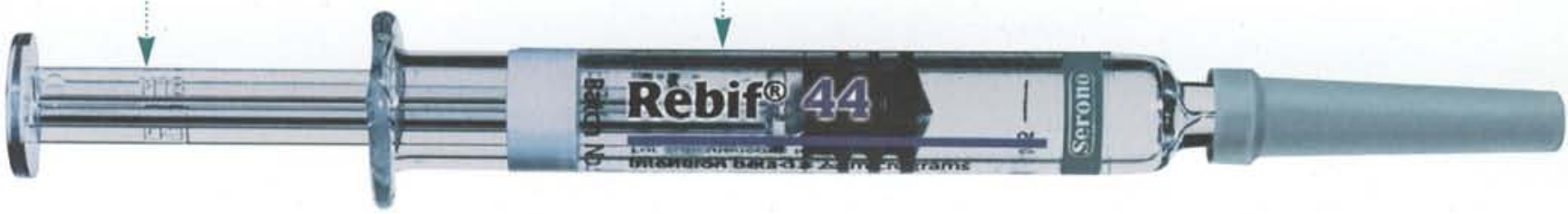

The most common reported adverse events are injection-site reactions and flu-like symptoms - e.g., asthenia, pyrexia, chills, arthralgia, myalgia, and headache. These tend to decrease in frequency and severity with continued treatment. Please see product monograph for full prescribing information. Evidence of safety and efficacy derived from 2-year data only.

* Rebif" is indicated for the treatment of relapsing-remitting multiple sclerosis in patients with an EDSS between 0 and 5.0, to reduce the number and severity of clinical exacerbations, slow the progression of physical disability, reduce the requirement for steroids, and reduce the number of hospitalizations for treatment of multiple sclerosis.

REFERENCES:

PRISMS (Prevention of Relapses and Disability by Interferon B-1 a Subcutaneously in Multiple Sclerosis) 
NOTE OUR NEW

ADDRESS DETAILS

ON A-2

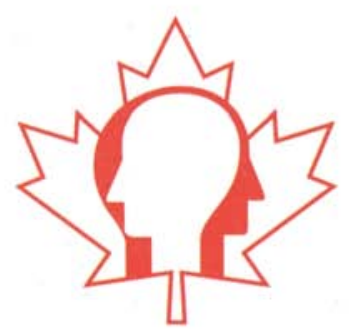

\section{THE CANADIAN JOURNAL OF}

Neurological Sciences

LE JOURNAL CANADIEN DES

\section{Sciences Neurologiques}

\section{EDITORIALS}

187 Oligodendrogliomas: The Achilles' Heel of Malignant Gliomas

Peter A. Forsyth and Douglas A. Stewart

189 Do Case Series have a Role in an Evidence-Based Medical Culture?

Vera Bril

\section{REVIEW ARTICLES}

191 Invited Review: Status of Current Clinical Trials in Diabetic Polyneuropathy

Vera Bril

199 Progress in Clinical Neurosciences:

Charcot-Marie-Tooth Disease and Related Inherited Peripheral Neuropathies

Timothy J. Benstead and Ian A. Grant

\section{ORIGINAL ARTICLES}

215 PCV for Oligodendroglial Tumors: In Search of Prognostic Factors for Response and Survival

David Fortin, David. R. Macdonald, Larry Stitt, J. Gregory Cairncross

224 Methylprednisolone May Improve Lumbosacral Radiculoplexus Neuropathy

P. James B. Dyck, Jane E. Norell, and Peter James Dyck

228 Neurocognitive Symptoms and Impairment in an HIV Community Clinic

D.H. Kim, D.L. Jewison, G.R. Milner, S.B. Rourke, M.J. Gill, C. Power

232 Methodology for the Canadian Activase for Stroke Effectiveness Study (CASES)

Michael D. Hill, Alastair M. Buchan and the CASES Investigators

239 Prospective Analysis of Relationships of Outcome Measures for Ulnar Neuropathy at the Elbow

Rajiv Midha, Jason Noble, Vivek Patel, Peter H. Ho, Catherine A. Munro, John Paul Szalai

245 Identification of the Temporal Components of Seizure Onset in the Scalp EEG

Nora S. O'Neill, Manouchehr Javidan, Zoltan J. Koles

\section{NEUROIMAGING HIGHLIGHT}

254 Shah-Naz Hayat Khan, Suzanne Hattingh, Robert William Griebel

\section{CASE REPORTS}

256 Endovascular Treatment of a Lenticulostriate Artery Aneurysm with N-butyl Cyanoacrylate Ramiro Larrazabal, David Pelz, J. Max Findlay

260 Encephalopathy with Staphylococcal Endocarditis: Multiple Neuropathological Findings

S.G. Weeks, C. Silva, R.N. Auer, C.J. Doig, M.J. Gill, C. Power

265 Spontaneous Internal Carotid Artery Dissection with Lower Cranial Nerve Palsy

N. Guy, D. Deffond, J. Gabrillargues, N. Carriere, G. Dordain, P. Clavelou

\section{IN MEMORIAM}

270 Mary Anne Lee

Douglas Zochodne

272 Letter to the Editor

273 Books Received

274 Book Reviews

279 Calendar of Events

280 Notes and Announcements

A-8 Information for Authors

A-14 25 Years ago in the Canadian Journal of Neurological Sciences

A-20 4th Annual Neurology Residents Headache Course

A-26 37th Meeting of the Canadian Congress of Neurological Sciences, Vancouver, British Columbia, with the Australian Association of Neurologists

A-58 Advertisers Index 


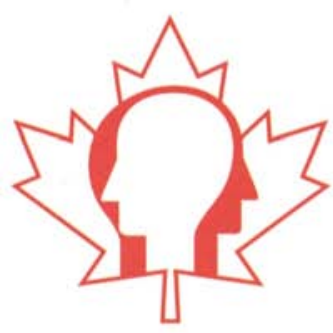

THE CANADIAN JOURNAL OF

Neurological Sciences

\section{LE JOURNAL CANADIEN DES Sciences Neurologiques}

Editor-in-Chief/Rédacteur en chef

Douglas W. Zochodne CALGARY, AB

Associate Editors/Rédacteurs associés

William A. Fletcher CALGARY, AB

Andres M. Lozano TORONTO, ON

Past Editors/Anciens rédacteurs en chef

James A. Sharpe TORONTO, ON

Robert G. Lee CALGARY, AB

Robert T. Ross WINNIPEG, MB

(Emeritus Editor, Founding Editor)

Editorial Board/Conseil Scientifique

Jack P. Antel MONTREAL, QC

Timothy J. Benstead HALIFAX, NS

J. Gregory Cairncross LONDON, ON

Andrew A. Eisen VANCOUVER, BC

J. Max Findlay EDMONTON, AB

Anthony M. Hakim OTTAWA, ON

Renn Holness HALIFAX, NS

Alan C. Jackson KINGSTON, ON

Douglas Kondziolka PITTSBURGH, PA, USA

Mark J Morrow Cleveland, OH, USA

Terence Myles CALGARY, AB

John H. Noseworthy ROCHESTER, MN, USA

C. Warren Olanow NEW YORK, NY, USA

David Ramsay LONDON, ON

Peter M. Richardson LONDON, UK

Guy Rouleau MONTREAL, QC

Shashi S. Seshia WINNIPEG, MB

Paul Steinbok VANCOUVER, BC

Jonathan A. Stoessl VANCOUVER, BC

\section{SECTION EDITORS/CONSEIL DE RÉDACTION}

Neuroimaging Highlight/Neuroimagerie

Mark Hudon CALGARY, AB

William Hu CALGARY, AB

Neuropathological Conference/Conférence sur la neuropathologie

David Ramsay LONDON, ON

Book Review/Critiques de livres

Warren P. Mason TORONTO, ON

\section{Managing Director/Gérant directrice}

Sally A. Gregg CALGARY, AB

\section{Publications Committee/Comité de Rédaction}

G. Bryan Young LONDON, ON

Owen Williams WINNIPG, MB

Joseph Chu ETOBICOKE, ON

Noel Lowry SASKATOON, SK
The official journal of: / La Revue officielle de:

The Canadian Neurological Society La Société Canadienne de Neurologie

The Canadian Neurosurgical Society

La Société Canadienne de Neurochirurgie

The Canadian Society of Clinical Neurophysiologists

La Société Canadienne de Neurophysiologie Clinique

The Canadian Association of Child Neurology

L'Association Canadienne de Neurologie Pédiatrique

The permanent secretariat for the four societies and the Canadian Congress of Neurological Sciences is at/

Le secrétariat des quatre associations et du Congrès Canadien des Sciences Neurologiques est situe en permanence à:

709 - 7015 Macleod Trail SW, Calgary AB, Canada T2H 2K6,

The Canadian Journal of Neurological Sciences is published quarterly. The annual subscription rate is $\$ 70$ for members; $\$ 77$ for non-members in Canada: $\$ 88$ for USA and elsewhere. Residents, Interns, Pre- and Post-Doctoral Students $\$ 35$ per annum (members); $\$ 38.50$ per annum (non-members). Single copies $\$ 22$ each plus postage and handling. All manuscripts and communications should be sent to: Canadian Journal of Neurological Sciences, P.O. Box 5456, Station A Calgary, AB Canada T2H IX8. Courier to: 709 - 7015 Macleod Trail SW Calgary, AB Canada T2H 2K6. Telephone (403) 229-9575; Fax (403) 2291661. E-mail: journal@cjns.org; Web Site: www.cjns.org COPYRIGHTO 2001 by THE CANADIAN JOURNAL OF NEUROLOGICAL SCIENCES INC. No part of this journal may be reproduced in any form without the prior permission of The Canadian Journal of Neurological Sciences. Mailed under Publications Mail Registration number 09824. Postage paid at Calgary, Alberta. This journal is indexed by Index Medicus, EMBASE Excerpta Medica and Current Contents - Clinical Practice and Life Sciences, Elsevier Biobase/Current Awareness in Biological Sciences, Biological Abstracts, Chemical Abstracts, Current Advances in Ecological Sciences, Dentindex, Industrial Medicine, Industrial Science Reviews, INIS Automind, Nutrition Abstracts, Science Citation Index, Weed Abstract.

Le Journal Canadien des Sciences Neurologiques est publié trimestriellement. L'abonnement anmuel est de $70 \$$ pour les membres; $77 \$$ pour les non-membres au Canada; 88 \$ pour les Etats Unis et ailleurs. Internes, résidents, fellows pré et post doctoral: $35 \$$ par année (membres); 38,50 \$ par année (non-membres). Copie simple: $22 \$$ plus affranchissement et manutention. Toutes les communications et les manuscrits doivent être adressés à Journal Canadien des Sciences Neurologiques, P.O. Box 5456, Station A, Calgary, AB Canada T2H 1X8. Par courrier: 709 - 7015 Macleod Trail SW, Calgary, AB Canada T2H 2K6. Téléphone (403) 229-9575; Fax (403) 229-1661. E-mail journal@cjns.org; Web Site: www.cjns.org

DROITS D'AUTEUR@ 2001: THE CANADIAN JOURNAL OF NEUROLOGICAL SCIENCES INC. Aucune partie de ce Journal ne peut êtr reproduite, sous quelque forme que ce soit, sans la l'authorisation du Journal Canadien des Sciences Neurologiques. Posté sous registration de poste-publications no 09824. Port payé à Calgary, Alberta. Le Joumal est cité et indexé dans Index Medicus, EMBASE Excerpta Medica et Current Contents - Clinical Practice et Life Sciences, Elsevier Biobase/Current Awareness in Biological Sciences, Biological Abstracts, Chemical Abstracts, Elsevier Biohase/Current Advances in Ecological Sciences, Dentindex, Industrial Medicine, Industrial Science Reviews, INIS Automind, Nutrition Abstracts, Science Citation Index. Weed Abstract.

Advertising representative/Représentant de publicité:

Sally Gregg, Canadian Journal of Neurological Sciences

709 - 7015 Macleod Trail SW, Calgary, AB Canada T2H 2K6 Tel (403) 229-9575 Fax (403) 229-1661

E-mail: journal@cjns.org

Web Site: www.cjns.org

Printer/Imprimeur:

Sundog Printing Limited, 1311 Ninth Avenue SW, Calgary, Alberta T3C $0 \mathrm{H} 9$

ISSN 0317 - 1671 


\section{Are you using ASA for the prevention of a second stroke?}

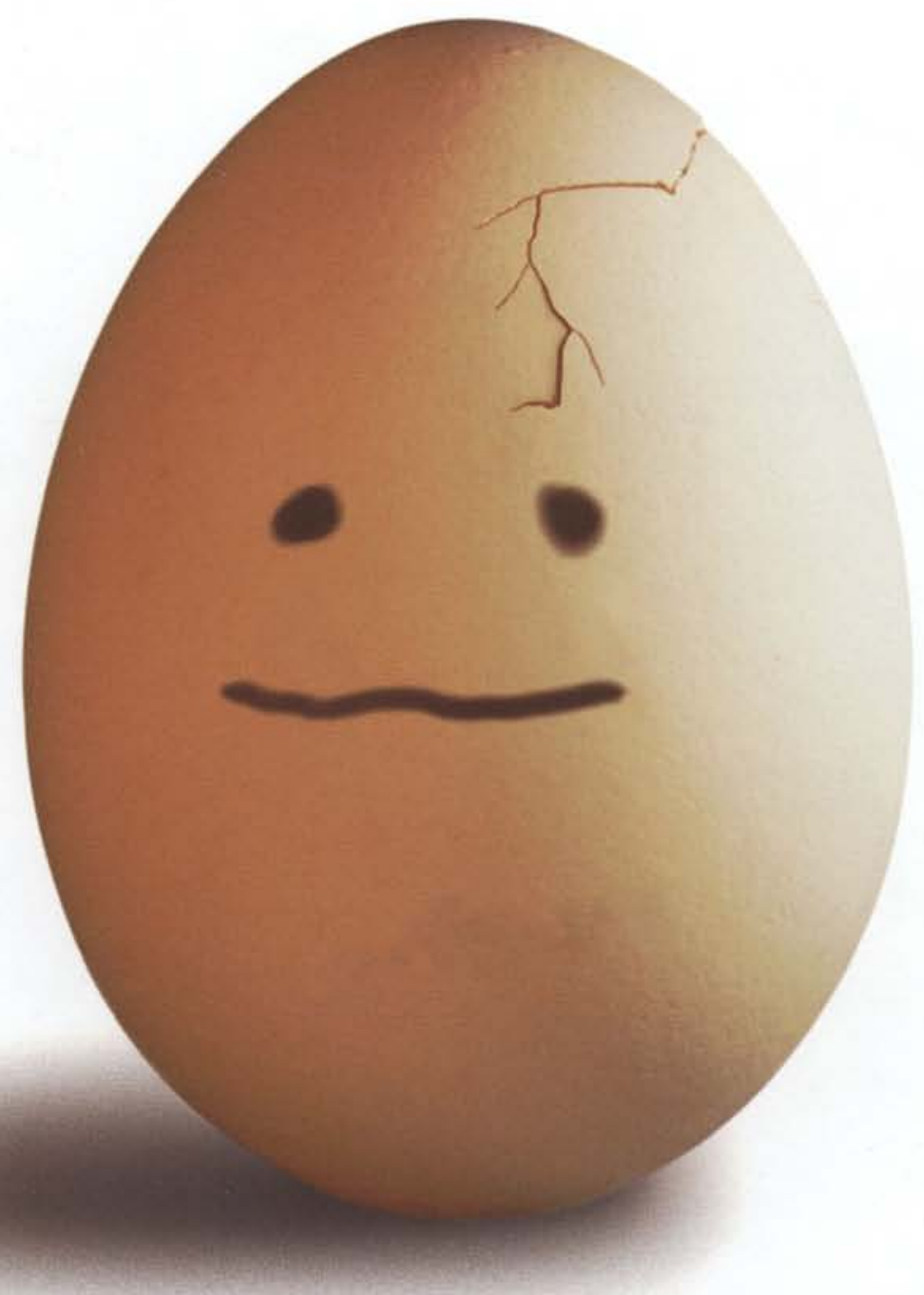

"Every patient who has experienced an atherothrombotic ... stroke or TIA and has no contraindication should receive an antiplatelet agent regularly..."

- Fifth ACCP Consensus Conference on Antithrombotic Therapy'

\section{Reassess your options...}




\section{For a brighter}

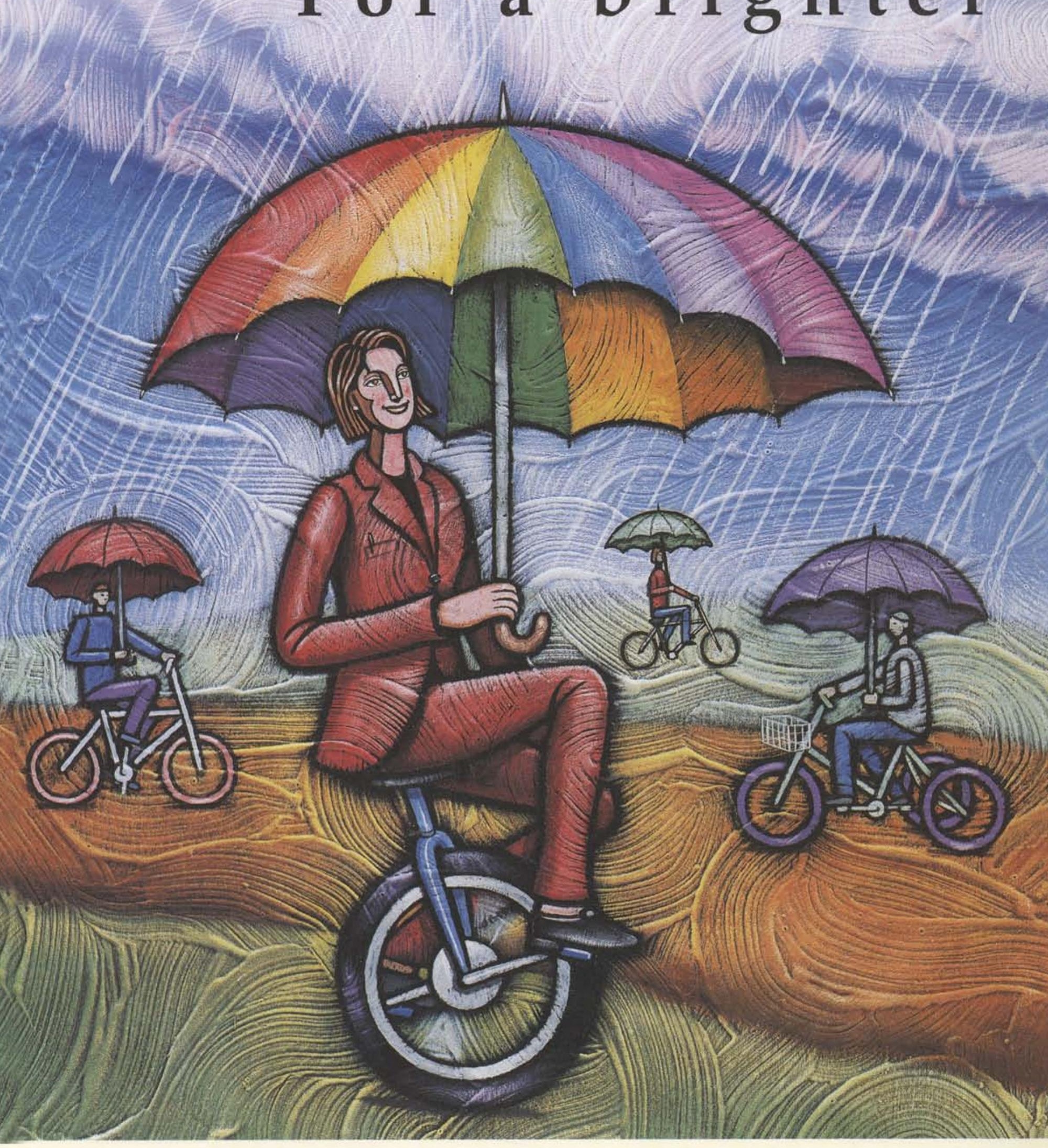




\section{future in epilepsy}

\section{For monotherapy after polytherapy in a wide range of seizure types}

Clinical trials have demonstrated that converting patients from polytherapy to monotherapy with LAMICTAL can maintain or even improve control over a wide range of seizure types.* And LAMICTAL monotherapy was generally well tolerated.' The most common adverse experiences associated with discontinuation of LAMICTAL monotherapy were rash $(6.1 \%)$, asthenia (1.1\%), headache $(1.1 \%)$, nausea $(0.7 \%)$ and vomiting $(0.7 \%)$.

\section{For control of Lennox-Gastaut syndrome}

LAMICTAL is the first and only of the newer antiepileptic drugs ${ }^{\dagger}$ (AED) indicated as adjunctive therapy for pediatric and adult patients with LennoxGastaut syndrome (LGS). LAMICTAL offers significantly improved control ${ }^{\ddagger}$ over the wide range of seizure types associated with Lennox-Gastaut syndrome, including major seizures, drop attacks and tonic-clonic seizures. Yet LAMICTAL has demonstrated a low CNS side effect profile ${ }^{i * *+}$ and has been reported to improve neurological function and cognitive skills, such as behaviour, speech and non-verbal communication.

\footnotetext{
* Please refer to Product Monograph for dose adjustment of LAMICTAL according to the concomitant AED withdrawn.

+ Refers to lamotrigine, gabapentin, vigabatrin and topiramate, to be distinguished from standard AEDs.

$\ddagger$ Versus placebo.

$\S$ With the exception of atypical absence seizures

II Frequently reported adverse events were pharyngitis (14\%), infection (13\%), vomiting (9\%) and rash (9\%).

** Rarely, serious skin rashes, including Stevens-Johnson syndrome and toxic epidermal necrolysis (Lyell syndrome), have been reported. Although the majority recover following drug withdrawal, some patients experience irreversible scaring and there have been rare cases of associated death.

+ DO NOT EXCEED the recommended initial dose and subsequent dose escalations of LAMICTAL. More rapid initial titration has been associated with an increased incidence of serious dermatological reactions.

(8) Lamictal is a registered trademark, used under license by GlaxoSmithKline Inc.
}

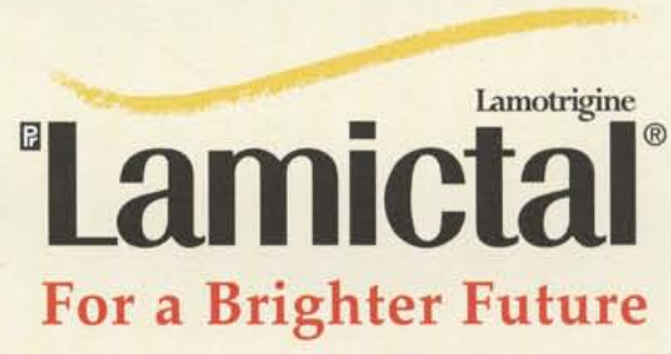


Consider
the evidence 


\section{$\mathrm{AVONEX}^{\circledR}$ is proven effective in Relapsing Remitting MS}

- $37 \%$ reduction in the probability of disability progression over two years $(21.9 \% \text { vs. } 34.9 \% \text { : } p=0.02)^{9.12}$

- $32 \%$ reduction in the annual exacerbation rate over two years (0.61 vs. 0.90: $\mathrm{p}=0.002)^{* 1.2}$

- $38 \%$ of patients remained relapse free at two years $(\mathrm{p}=0.03)^{\infty .12}$

- $55 \%$ reduction in brain atrophy progression during the second year of therapy $(-0.233 \text { vs, }-0.521 ; p=0.03)^{ \pm 3}$

- $89 \%$ reduction in gadolinium-enhanced lesions in patients with enhancement at baseline (0.11 vs. 0.50: $\mathrm{p}=0.041)^{\dagger+4}$

- AVONEX ${ }^{\circledR}$ is indicated for the treatment of relapsing forms of MS.

AVONEX is generally well tolerated. The most common side effects associated with treatment are flu-like symptoms (muscle ache Imyalgial, fever. chills. and asthenia). Please see product monograph for important patient selection and monitoring information.' AVONEX ${ }^{\circledR}$ should be used with caution in patients with depression and in patients with seizure disorders. AVONEX should not be used by pregnant women. Patients with cardiac disease should be closely monitored. Routine periodic blood chemistry and hematology tests are recommended during treatment with AVONEX!

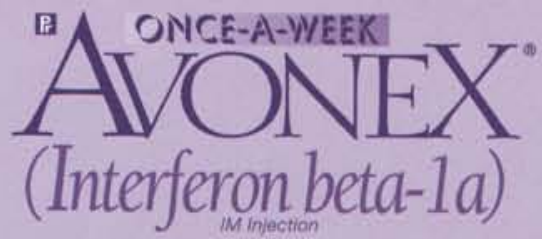

q Kaplan-Meier methodology. AVONEX $n=158$, placebo $n=143$.

* AVONEX $n=85$, placebo $n=87$

(16) $n=85$.

* As measured by brain parenchymal fraction in the second year of treatment. AVONEX $n=68$, placebo $n=72$. + AVONEX $^{\infty} n=44$, placebo $n=44$. The exact relationship between MRil findings and clinical status is unknown. Biogen Canada is a registered trademark of Biogen, Inc. AVONEX is a registered trademark of Biogen, Inc. 


\section{INFORMATION FOR AUTHORS}

The Canadian Journal of Neurological Sciences publishes original articles in neurology, neurosurgery and basic neurosciences. Manuscripts are considered for publication with the understanding that they, or the essence of their content, have not been published elsewhere except in abstract form and are not under simultaneous consideration by another journal. Articles undergo peer review. Manuscripts should be submitted to: Douglas Zochodne, M.D., Editor. Canadian Journal of Neurological Sciences, P.O. Box 5456, Station A, Calgary, AB, Canada T2H 1 X8

\section{Manuscript Preparation}

- Submit five high quality copies of the manuscript and original illustrations. Papers will be accepted in English or French. Manuscripts must be double spaced throughout including references, tables and legends for illustrations. Margins of at least $25 \mathrm{~mm}$ should be left on all sides.

- After a paper has been reviewed, the author will be requested to submit four copies of the revised manuscript, including illustrations. Supply a computer diskette ( $31 / 2^{\prime \prime}$ size) containing the article saved in an RTF format. Identify clearly first author's name, file name, word processing program and version, and system (i.e. PC or Mac). Clearly indicate the order and importance of headings.

- For detailed instructions regarding style and layout refer to "Uniform requirements for manuscripts submitted to biomedical journals". Copies of this document may be obtained by writing to the Journal office, but the main points are summarized here. Articles should be submitted under conventional headings of introduction, methods and materials, results, discussion, but other headings will be considered if more suitable. Clinical trials must be reported in Consort format (JAMA 1996; 276: 637-639). Pages of text should be numbered consecutively.

- A title page should identify the title of the article which should be no more than 80 characters including spaces; name of institution(s) from which the work originated; and the name, address, telephone, and fax number of the corresponding author.

- Abstract Original Articles should be accompanied by an abstract of 250 words or less on a separate page, preferably in English and French, although the Journal will provide translation if required. Abstracts of original articles should consist of four paragraphs headed: Background (or objective), Methods, Results and Conclusions. Review articles should be accompanied by an abstract of 150 words or less.

- Acknowledgements including recognition of financial support should be typed on a separate page at the end of the text.

- The SI system (système international d'unités) should be used in reporting all laboratory data, even if originally reported in another system. Temperatures are reported in degrees celsius. English language text may use either British or American spelling, but should be consistent throughout.

- References should be numbered in the order of their citation in the text. Those cited only in tables and legends for illustrations are numbered according to the sequence established by the first identification in the text of a particular table or illustration. Titles of journals should be abbreviated according to the style used in Index Medicus. References should list the names of up to five authors; if there are more, cite the first three, then et al. Provide the full title, year of publication, volume number and inclusive pagination for journal articles. For any reference cited as "in press", five copies of the article must accompany the author's manuscript. Do not reference unpublished or "submitted" papers; these can be mentioned in the body of the text and authors must provide five copies of "submitted" manuscripts.
Avoid "personal communications" and, if necessary, include them in the body of the text, not among the references. Reference citations should not include unpublished presentations or other non-accessible material. Books or chapter references should also include the place of publication and the name of the publisher. Examples of correct forms of reference follow:

Journals

Yang JF, Fung M, Edamura R, et al. H-Reflex modulation during walking in spastic paretic subjects. Can J Neurol Sci 1991; 18: 443452.

Chapter in a book

McGeer PL, McGeer EG. Amino acid neurotransmitters. In: Siegel GJ, Albers RW, Agranoff BW, Katzman R, eds. Basic Neurochemistry. Boston: Little, Brown \& Co., 1981: 233-254.

- Illustrations Submit five original sets of illustrations. We will not return illustrations; therefore, authors should keep negatives for all photographs. Submit high quality glossy black and white photographs preferable $127 \times 173 \mathrm{~mm}\left(5^{\prime \prime} \times 7^{\prime \prime}\right)$. This includes graphs and diagrams. Do NOT send photocopies of illustrations. Original artwork and radiographs should not be submitted. The additional cost of coloured illustrations must be borne by the author; quotations are available upon request from the Journal office. Identify each figure with a label at the back indicating top, figure number and first author. Letters and arrows applied to the figures to identify particular findings should be professional appliques suitable for publication. Photomicrographs should include a calibration bar with a scale indicated on the figure or in the legend. Legends for illustrations should be typed on a separate page from the illustrations.

- Tables Type tables double-spaced on pages separate from the text. Provide a table number and title for each. Particular care should be taken in the preparation of tables to ensure that the data are presented clearly and concisely. Each column should have a short or abbreviated heading. Place explanatory matter in footnotes, not in the heading. Do not submit tables as photographs.

- Review articles on selected topics are also published. They are usually invited, but unsolicited reviews will be considered. It is recommended that authors intending to submit review articles contact the Editor in advance.

- Letters to the Editor concerning matters arising in recent articles are welcome. Letters should be limited to two double-spaced pages and may include one illustration and a maximum of four references.

- Permissions and Releases Any non-original material (quotations, tables, figures) must be accompanied by written permission from the author and the copyright owner to reproduce the material in the Journal. Permission must be for print and electronic media. Photographs of recognizable persons must be accompanied by a signed release from the legal guardian or patient authorizing publication.

- Conflict of Interest Authors who have non-scientific or non-academic gain whether it be financial or other from publishing their article are responsible for delaring it to the Editor. Any financial interest, research grant, material support, or consulting fee associated with the contents of the manuscript must be declared to the Editor. These guidelines apply to each author and their immediate families. conflicts of interest are not necessarily wrong nor do they necessarily change the scientific validity of research or opinion, but the Journal and readers should be aware of the conflict. If the Editor considers the conflict to compromise the validity of the paper, it will not be accepted for publication. Authors, editorial staff and reviewers are asked to declare any relationship that would be considered as a conflict of interest whether or not they believe that a conflict actually exists. Information that the Journal receives about conflict or potential conflict will be kept confidential unless the Editor or Associate Editor considers it to be important to readers. Such conflicts will be published in the author credits or as a footnote to the paper, with knowledge of the authors. 



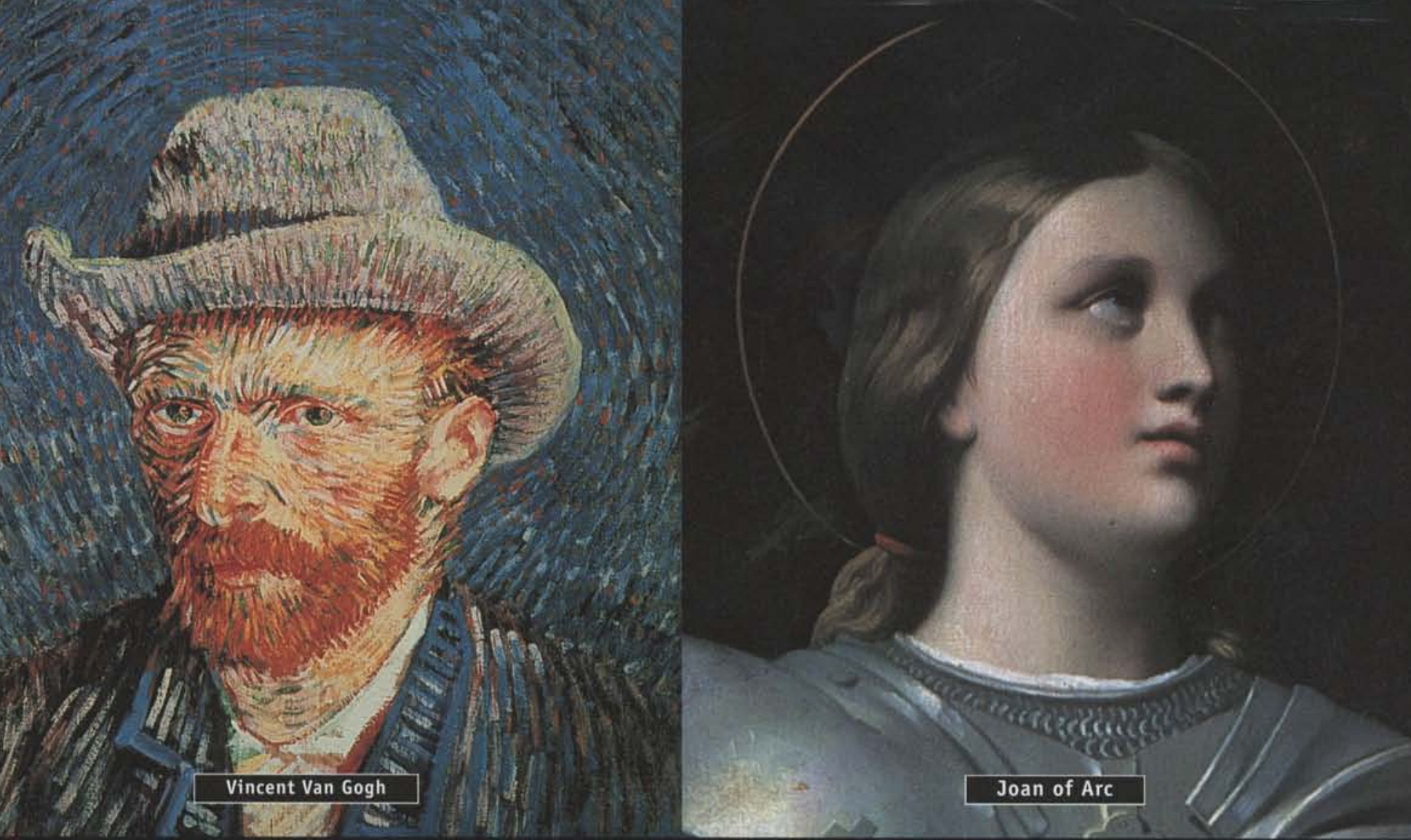

\section{YESTERDAY, PEOPLE WITH EPIHEPSY} HAD TO BE EXTRAORDINARY TO SUGGEED.
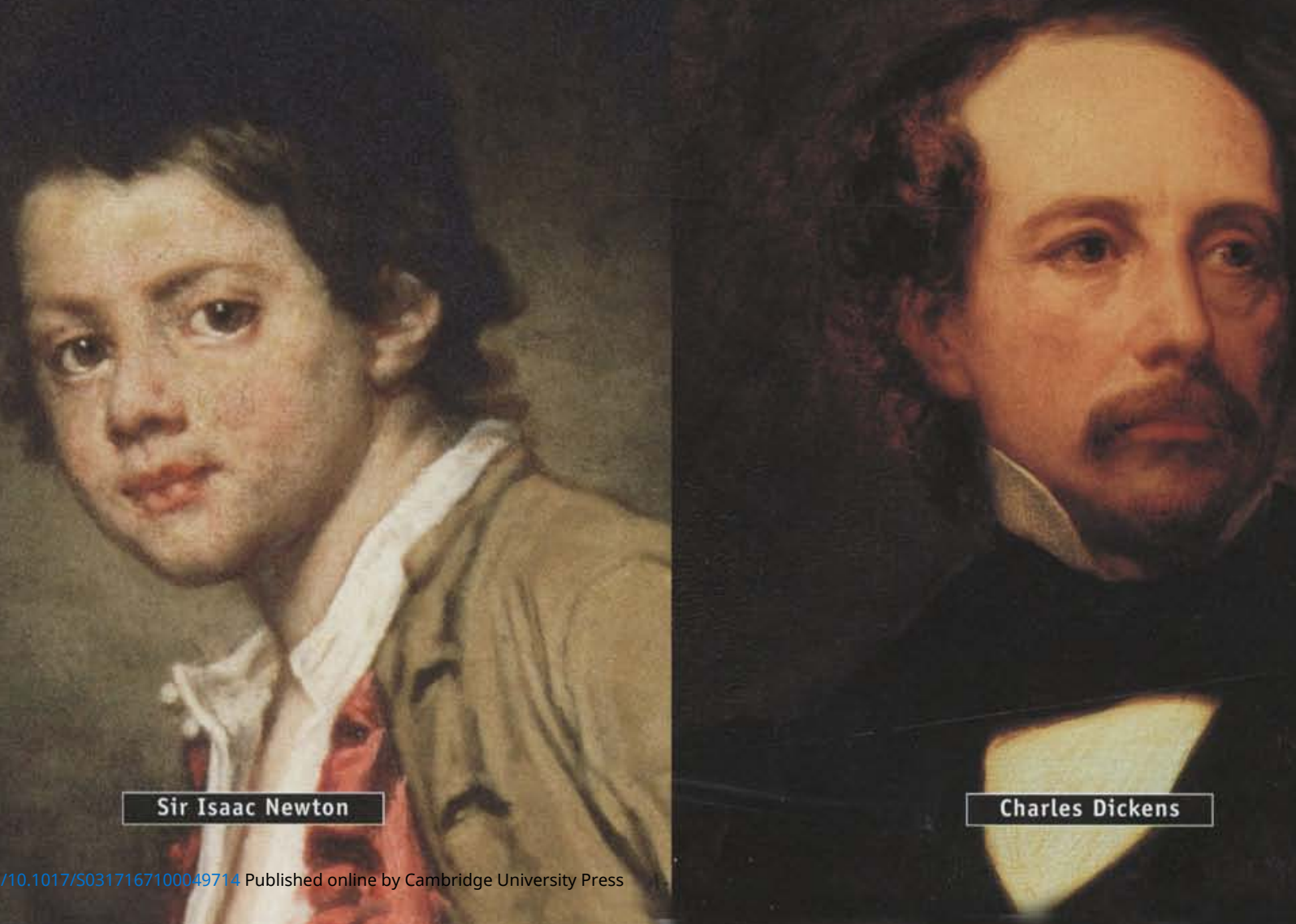


\section{EFFICACY ACROSS A BROD RANGE OF SEIZURES.}

- TOPAMAX demonstrates efficacy in Partial Onset, Primary Generalized Tonic-Clonic, and Lennox-Gastaut Seizures ${ }^{1}$

- Desirable seizure-free results were shown in both Adults $(19 \%)^{\dagger}$ and Children $(22 \%)^{\ddagger}$ with Partial Onset Seizures s.3 $^{2.3}$

\section{NO EVIDENCE OF LIFE-THREATENING SIDE EFFECTS.}

- Like most antiepileptics, the most common side effects are CNS related, usually mild to moderate and transient ${ }^{\$ 1}$

\section{ADULT PATIENTS MAY EXPERIENCE WEIGHT LOSS.}

- $73 \%$ of patients $(n=52)$ showed a mean weight decrease of $5.97 \mathrm{lb}$ (Interim analysis. Average duration 60 days) ${ }^{4}$

- $96 \%$ of children in clinical trials ( $\geq$ one year) who lost weight showed resumption of weight gain in test period" ${ }^{*}$

\section{TODAY, THERE'S TOPAMAX.}

\section{B.I.D. DOSING WITH THE PATIENT IN MIND.}

- TOPAMAX is initiated and titrated to clinical response regardless of existing anticonvulsant therapy

- Tablets available on formulary"t

NOW AVAILABLE

IN SPRINKLE CAPSULES
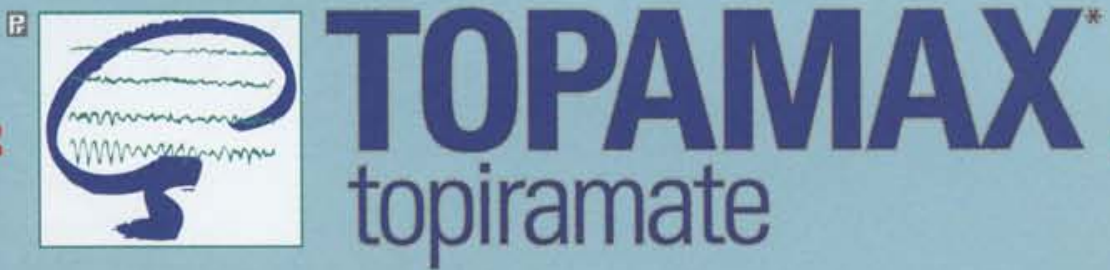

NOW INDICATED

FOR CKILDREN

\section{HELPING PATIENTS MAKE MORE OF THEIR LIVES.}

"TOPAMAX" topiramate Tablets and Sprinkle Capsules: indicated as adjunctive therapy for the management of patients (adults and children two years and older) with epilepsy who are not satisfactorily controlled with conventional therapy. There is limited information on the use of topiramate in monotherapy at this time!

10pen label, 20 week trial (n=-650 Adults). Optimal dosing was $300-350 \mathrm{mg} / \mathrm{day}$ (Average $288 \mathrm{mg} / \mathrm{day})$.

t Open label trial for children (nm72) treated for 23 months, Average dose of $10 \mathrm{mg} / \mathrm{kg} / \mathrm{day}$.

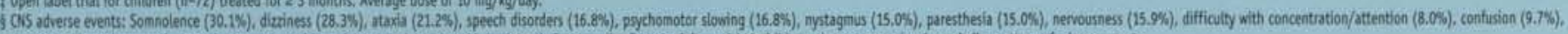
depression (8.0\%), andexia (5.3\%), language problems $(6.2 \%)$ and mood probiens $(3.5 \%)$. In an audit of 1446 adalts and 303 children, there appeared to be a similar pattern of atverse events.

$\because$ The long-term effects of veight loss in petiatric patients are not known.

It limited use benefit: Ontario, Nova Scota, New Brunswick, PEl. fall benefit: Quebec, Saskatchewan, British Columbia, Alberta, Maritoba,

Please refer to the TOPAMaX Prescribing Infornation for complate prescribing details.

REFfaENCEs: 1. TOPAMAX' topiramate Tablets and Sprinkle Capsules Product Monograph, May 11, 1999. 2. Kamin M, Kraut L, Obson W. Dose optimization of topiramate as add-on therapy in adults with traatnent-resistant partial-onset seizures Meurology 1999; 52 (Suppl 2):A525-526. 3. Glauser Th, Elterman R, Wyllie Eet al. Open label topiranate in paediatric partial epliepsy Epliepsio 1997:38 (Suppl 3):94, 4, Rosenfeld WE et aLTopiramate and concomitant weight loss. Epilepsio 1997:38 (Suppl 8):98. 


\section{Bayer Canada is looking for answers.}

\section{This is what we found.}

In making the decision to use

IVIG (Intravenous Immune Globulin) in

specific indications, Canadian physicians

rely on tools such as the published

literature and/or available guidelines.

The development of guidelines for

the appropriate use of IVIG was

sponsored by Bayer, who provided

an unrestricted educational grant,

including extensive literature review

and specialist consultation. ${ }^{4.5}$

A recent survey found that over $80 \%$

of IVIG use in Canadian hospitals

is in keeping with these consensus

guidelines for appropriate use?

But $80 \%$ is not $100 \%$.

\section{We're still looking.}

We spend $\$ 8 M$ in Research \&

Development, which includes IVIG use as a priority, and we are committed to sponsoring Canadian clinical trials to investigate

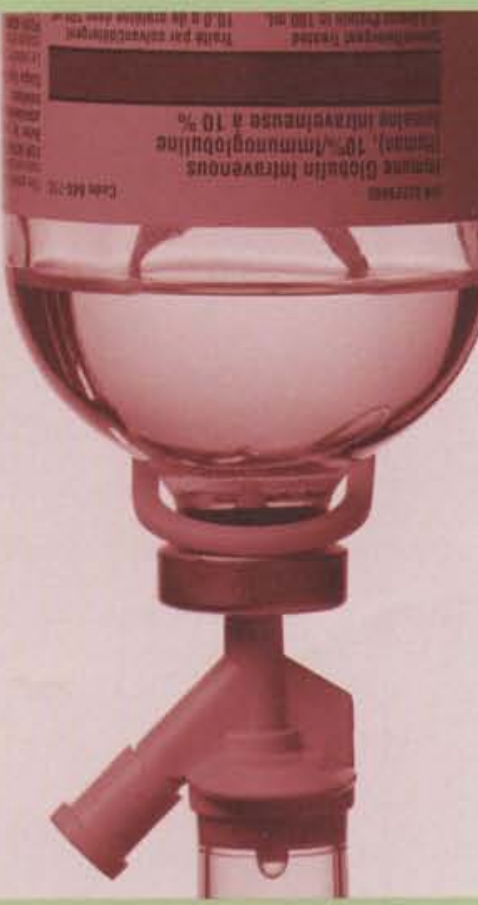
possible new indications.

And because physicians are the key, we also sponsor two Immunology Fellowships lone in co-operation with CIHRI worth $\$ 250,000$, and we develop and offer CME promoting appropriate use through Canadian hospitals. For more information about the Appropriate Use of IVIG, contact Bayer at gamimune.canada@bayer.com

\section{Appropriate Use.}

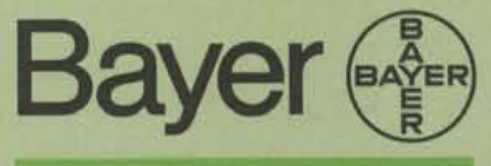

maker of Gamimune $\mathrm{N}, 10 \%$

\section{(RED)}

1. Gamimune Prescribing Information, 2001. 2. Gammagard Prescribing Information, 2001. 3. Iveegam Prescribing Information, 2001. 4. The Consensus Working Group. Present and Future Uses of IVIG: A Canadian Multidisciplinary Consensus-Building Initiative. Canadian Journal of Allergy \& Clinical Immunology 1997; 2(5): 176-208. 5. Brill V, Allenby K, Midroni G, O'Connor PW, Vajsar J. IVIG in Neurology - Evidence and Recommendations. Can J Neurol Sci 1999:26(2): 139-152. 6. Hanna K, Poulin-Costello M. Preston M, Maresky N. Intravenous Immune Globulin (IVIG) Utilization in Canada. Submitted. 


\title{
25 Years Ago in the Canadian Journal of Neurological Sciences
}

\section{Quebec Cooperative Study of Friedreich's Ataxia \\ Phase One: A Prospective Survey of 50 Cases}

Organized and Edited by André Barbeau

\section{DESIGN OF THE INVESTIGATION}

\section{A. Barbeau}

SUMMARY: The general outline of the complete prospective study of 50 cases of spinocerebellar a generation is given. The general protocol followed, the criteria for inclusion and the mode of analysis are described. The aim of this study was to establish a base of clinical, physiological and biochemical facts upon which a logical and systematic approach to pathogenesis and treatment of Friedreich's ataxia could be attempted.

Can. J. Neurol. Sci. 1976;4:271

\section{Nicolaus Friedreich And Degenerative Atrophy \\ of THE Posterior Columns of THE SPINAL CORD}

\section{F. Andermann}

SUMMARY: A short outline is given of the pioneer efforts of Nicolaus Friedreich in the description of the spinocerebellar degeneration which now bears his name.

Can. J. Neurol. Sci. 1976;4:275

\author{
Clinical Description and RoEntgenOlogic \\ Evaluation of Patients with Friedreich's AtaXia \\ G. Geoffroy, A. Barbeau, G. Breton, B. Lemieux, M. Aube, C. Leger and J.P. Bouchard
}

SUMMARY: The 50 patients in this survey were classified by a panel of neurologists into four clinical subgroups; Group Ia ("typical" Friedreich's ataxia, complete picture), Group Ib ("typical" Friedreich's ataxia, incomplete picture), Group IIa ("atypical" Friedreich's ataxia, possible recessive Roussy-Levy syndrome), Group IIb (heterogeneous ataxias). The clinical symptoms and signs were analyzed for each of these groups. A constellation of signs constantly present in Friedreich's ataxia and obligatory for diagnosis was described. Other important symptoms, such as the Babinski sign, kyphoscoliosis and pes cavus were found to be progressive, but not essential for the diagnosis at any given time. Finally, a host of other symptoms can only be called accessory. The progression of scoliosis was found to be an important tool in the differential diagnosis of ataxias. Our study also indicates, in contrast to the opinion of some authors, that absent deep tendon reflexes in the lower limbs and early dysarthria are essential in "typical" Friedreich's ataxia.

Can. J. Neurol. Sci. 1976;4:279 


\section{Introducing "Zanaflex A new option in the treatment of spasticity}

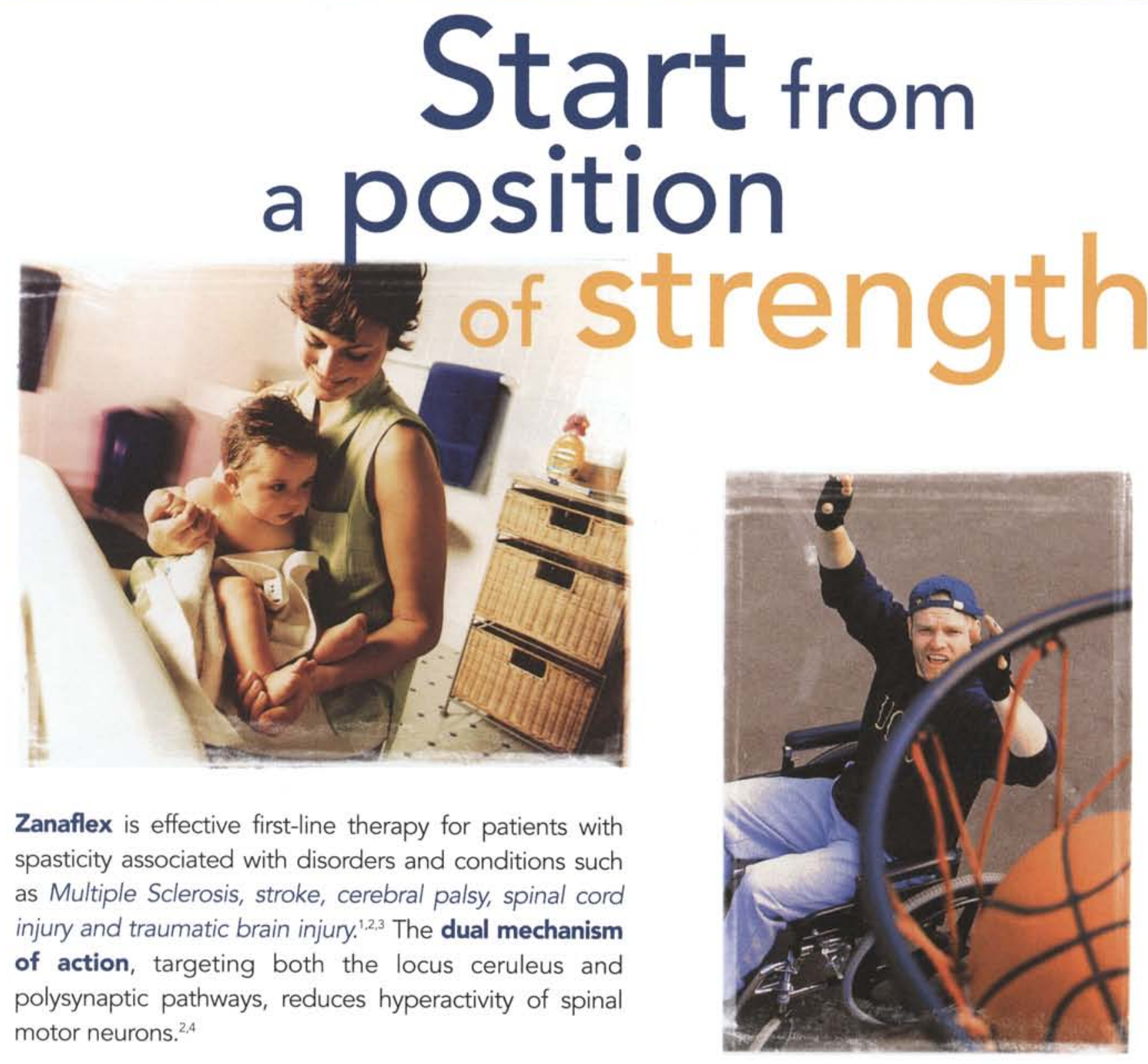

\section{Reduces muscle tone. Preserves muscle strength. ${ }^{1}$}

DRAXIS

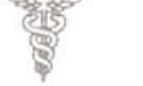

DRAXIS HEALTH INC.

6870 Goreway Drive,

(8) Zanaflex is a registered trademark of Elan Pharmaceuticals Inc.

DRAXIS HEALTH INC. is the Canadian distributor of Zanaflex.

In multiple-dose, placebo-controlled studies, the most frequently reported adverse events included dry mouth $(49 \%)$, sedation/somnolence $(48 \%)$, asthenia (weakness, fatigue and/or tiredness) $(41 \%)$ and dizziness $(16 \%)$. “The most common adverse events leading to discontinuation of therapy were asthenia (3\%), somnolence (3\%) and dry mouth (3\%).

Sedation may be additive when Zanaflex is taken in conjunction with drugs or substances that act as CNS depressants. Caution is advised when treatment is used in patients who have a history of orthostatic hypotension or are receiving concurrent antihypertensive therapy. Monitoring of aminotransferase levels is recommended during the first six months of treatment, and periodically thereafter, based on clinical status.

\section{For more information,} call 1-800-563-7546.

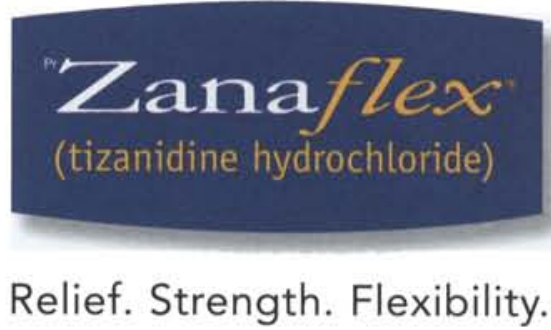




\section{$L^{\prime}$ a v e n i r}

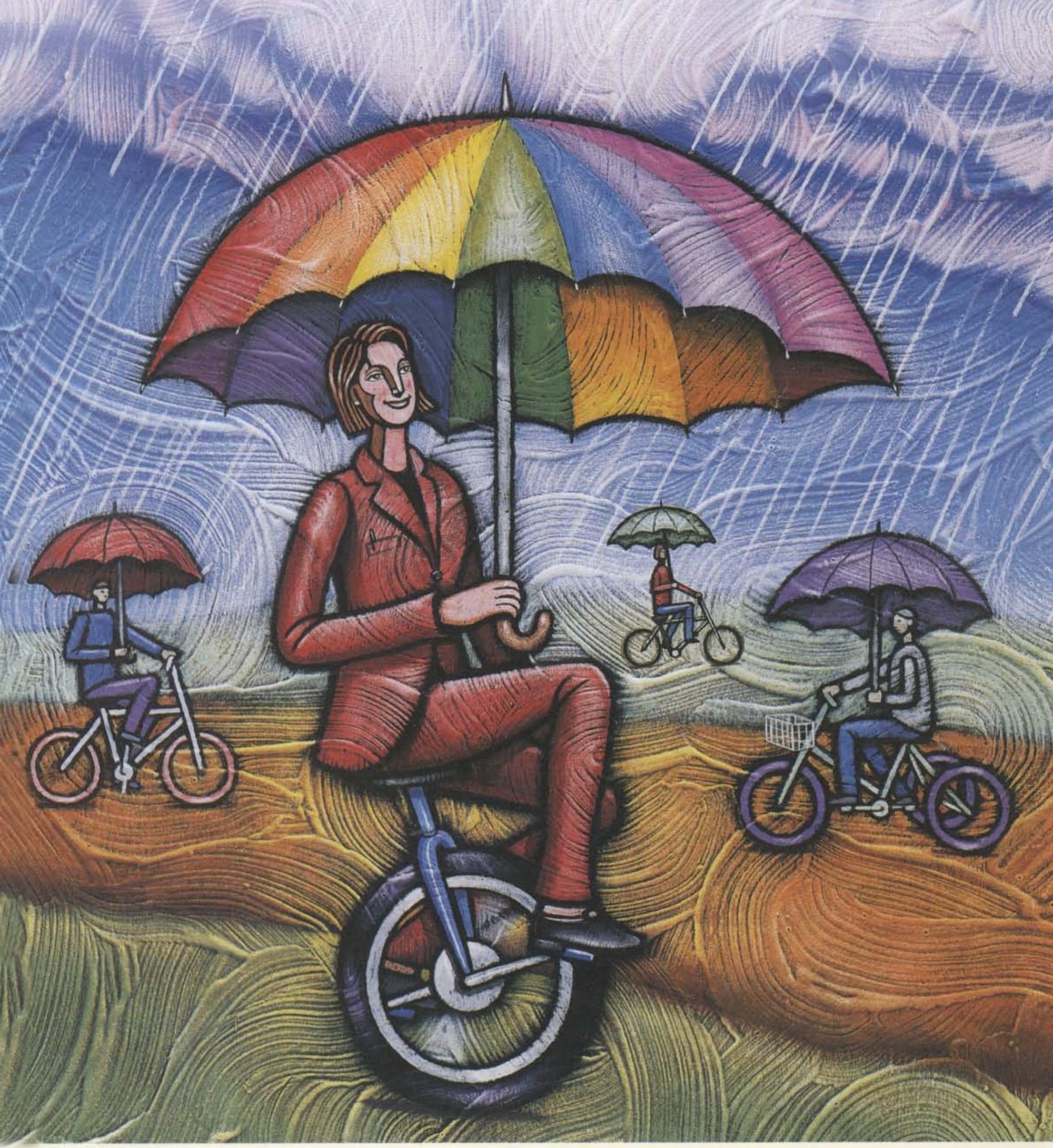




\section{Pour passer à la monothérapie après une polythérapie, dans le traitement de diverses crises épileptiques.}

Lors d'essais cliniques, on a pu constater que le passage de la polythérapie à la monothérapie par LAMICTAL peut maintenir ou même améliorer la maîtrise d'un vaste éventail de crises épileptiques*. La monothérapie par LAMICTAL a été généralement bien tolérée ${ }^{1}$. Les effets indésirables les plus souvent associés à l'abandon de la monothérapie par LAMICTAL ont été l'éruption cutanée $(6,1 \%)$, l'asthénie $(1,1 \%)$, la céphalée $(1,1 \%)$, la nausée $(0,7 \%)$ et les vomissements $(0,7 \%)$.

\section{Pour maîtriser le syndrome de Lennox-Gastaut}

LAMICTAL est le premier et le seul parmi les nouveaux antiépileptiques ${ }^{\dagger}$ qui est indiqué comme traitement d'appoint chez les enfants et les adultes atteints du syndrome de Lennox-Gastaut. LAMICTAL offre une maîtrise significativement supérieure ${ }^{\ddagger} \mathrm{d}^{\prime}$ un vaste éventail de crises épileptiques associées au syndrome de Lennox-Gastaut ${ }^{\S}$, y compris les crises majeures, les effondrements épileptiques et les crises tonico-cloniques. LAMICTAL a démontré peu d'effets indésirables ${ }^{q * *+}$ sur le SNC. Il a été associé à une amélioration de la fonction neurologique et des facultés cognitives, comme le comportement, la parole et la communication non verbale ${ }^{\ddagger}$.

* Veuillez consulter la monographie du produit afin d'ajuster les doses de LAMICTAL selon l'antiépileptique concomitant faisant l'objet du retrait.

+ Lamotrigine, gabapentine, vigabatrine et topiramate (à distinguer des antiépileptiques standards).

‡ Comparativement au placebo.

$\S$ À l'exception des absences épileptiques atypiques.

II Les effets indésirables fréquemment signalés étaient : pharyngite (14\%), infection (13\%), vomissements $(9 \%)$ et éruptions cutanées (9\%).

* Dans de rares cas, des éruptions cutanées graves, y compris le syndrome de Stevens-Johnson et 1'épidermolyse nécrosante suraiguë (syndrome de Lyell), ont été signalées. Bien que la majorité des patients se soient rétablis après le retrait du médicament, certains ont présenté des séquelles irréversibles et il y a eu de rares cas de décès associés.

+t NE PAS DEPASSER la dose initiale de lamotrigine ni l'augmentation posologique graduelle qui sont recommandées. Une augmentation plus rapide de la dose initiale a été associée à une fréquence accrue de réactions dermatologiques graves.

(B) Lamictal est une marque déposée, utilisée sous licence par GlaxoSmithKline Inc.

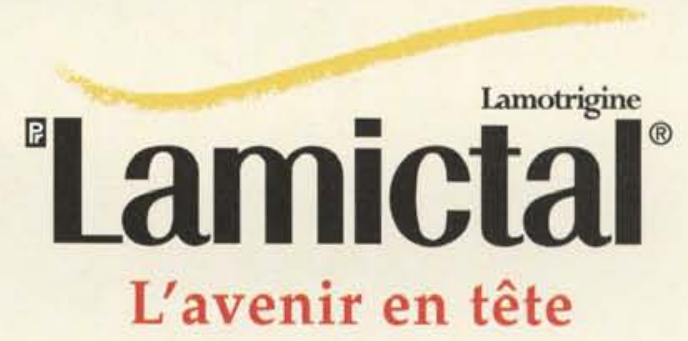




\section{SINCE 1997, COPAXONE HAS BEEN AVAILABLE TO HELP MEET YOUR NEEDS AND THOSE OF YOUR RRMS PATIENTS.}

For the reduction of relapse frequency in ambulatory patients with relapsing-remitting multiple sclerosis...

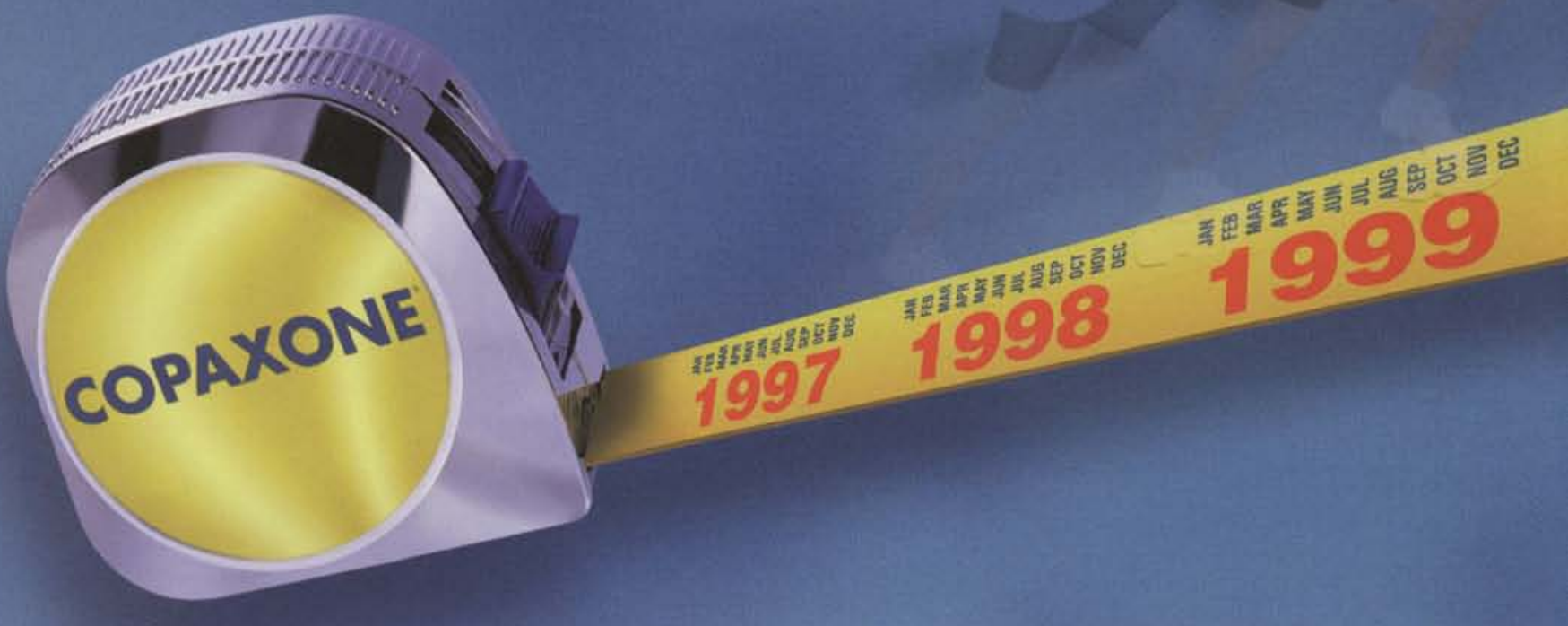

COPAXONE is an excellent choice for early treatment.

COPAXONE ${ }^{\circ}$ has a side effect profile that compares to placebo and is an excellent choice to start with.

In clinical trials, only $8 \%$ of 844 patients discontinued treatment due to an adverse event. ${ }^{1}$ The most commonly observed adverse events associated with the use of COPAXONE ${ }^{\circ}$ in controlled clinical trials which occurred at a higher frequency than placebo were':

\begin{tabular}{|c|c|c|}
\hline Adverse Event & $\begin{array}{l}\text { Non-interferon } \\
\text { COPAXONE }\end{array}$ & Placebo \\
\hline Injection Site Reactions ${ }^{\dagger}$ & $2.4 \%-66.4 \%$ & $0.0 \%-36.5 \%$ \\
\hline Asthenia & $64.8 \%$ & $61.9 \%$ \\
\hline Hypertonia & $35.2 \%$ & $29.4 \%$ \\
\hline Vasodilatation & $27.2 \%$ & $11.1 \%$ \\
\hline Back Pain & $26.4 \%$ & $22.2 \%$ \\
\hline Chest Pain & $26.4 \%$ & $10.3 \%$ \\
\hline Arthralgia & $24.8 \%$ & $17.5 \%$ \\
\hline Nausea & $23.2 \%$ & $17.5 \%$ \\
\hline Pain (Neck) & $12.8 \%$ & $7.1 \%$ \\
\hline Infection (Vaginal Moniliasis) & $12.8 \%$ & $7.1 \%$ \\
\hline Agitation (Anxiety) & $5.6 \%$ & $3.2 \%$ \\
\hline
\end{tabular}




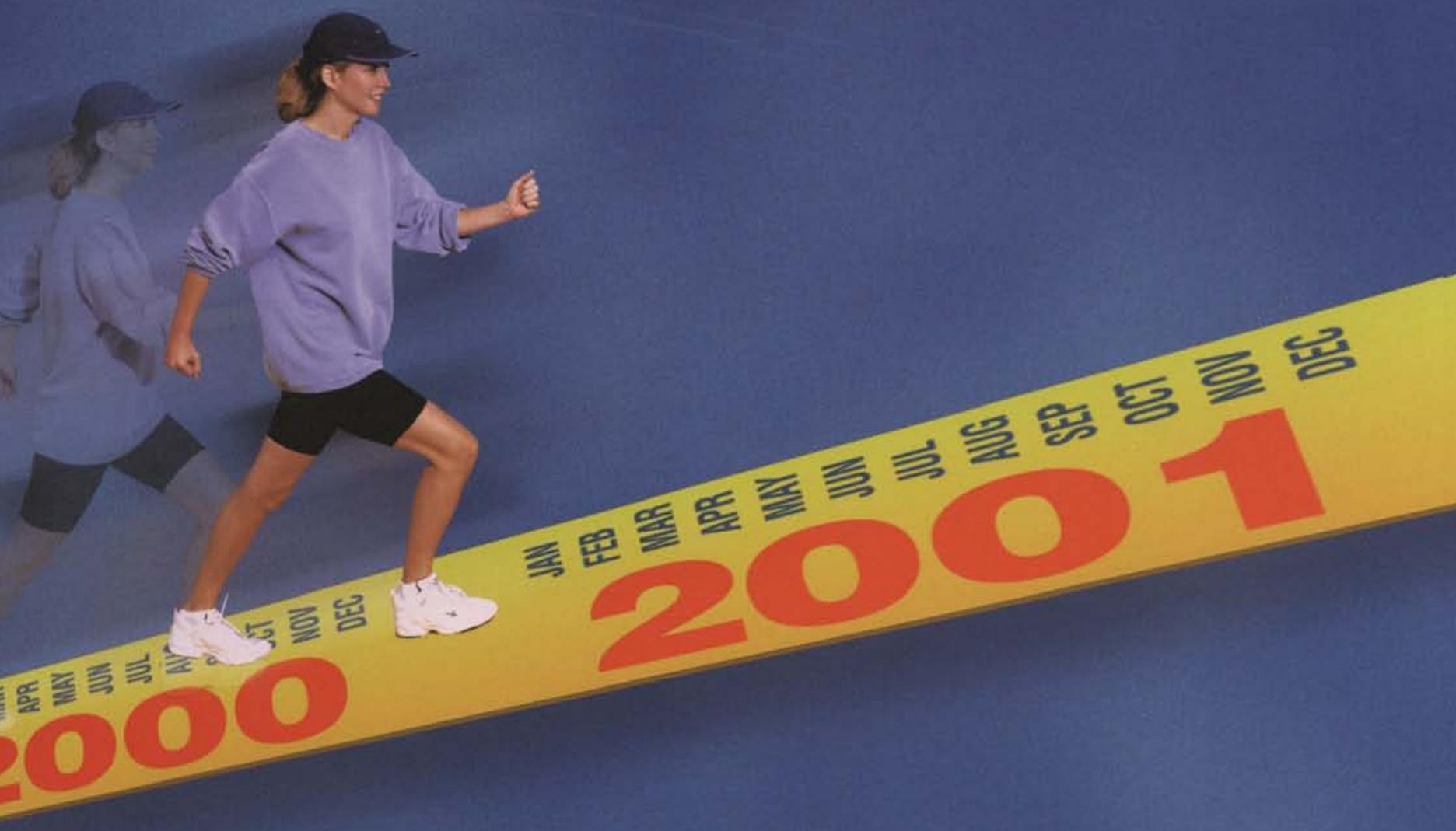

\section{COPAXONE ${ }^{\circ}$ is an excellent choice for the long-term (2 years), too.}

COPAXONE ${ }^{\circ}$ is supported by long-term evidence of up to 2 years and efficacy that's been demonstrated in 6 clinical studies. ${ }^{2-7}$ A correlation between a reduction in attack frequency and a decreased risk of future disability remains to be established. The safety and efficacy of COPAXONE ${ }^{*}$ beyond two years have not been adequately studied in placebo-controlled trials.

$\mathrm{COPAXONE}^{\circ}$ is an antigenic substance and thus, it is possible detrimental host responses can occur with its use.

\section{Only COPAXONE ${ }^{\circ}$ has Shared Solutions ${ }^{\mathrm{TM}}$.}

Shared Solutions ${ }^{\mathrm{TM}}$ helps support patients through early treatment and in the long-term (January 1999-March 2000 data)." With Shared Solutions sM $^{\mathrm{M}}$, $93 \%$ of COPAXONE ${ }^{\circ}$ patients stayed on therapy. ${ }^{8}$

\section{'COPAXONE"} (glatiramer acetate for injection)

\section{EFFICACY BACKED BY EVIDENCE}

Shared Solutions ${ }^{\mathrm{TM}}$ is a trademark of Teva Marion Partners Canada ${ }^{\mathrm{TM}}$. COPAXONE is a registered trademark of Teva Pharmaceuticals Ltd. and is used under licence. TEVA and the design version thereof are trademarks of Teva Pharmaceutical Industries Ltd. and are used under licence. MARION and the design version thereof are trademarks of the Aventis Group and are used under licence by Aventis Pharma Inc. (C2001 Teva Marion Partners Canada ${ }^{\mathrm{TM}}$.

Product Monograph available on request. 


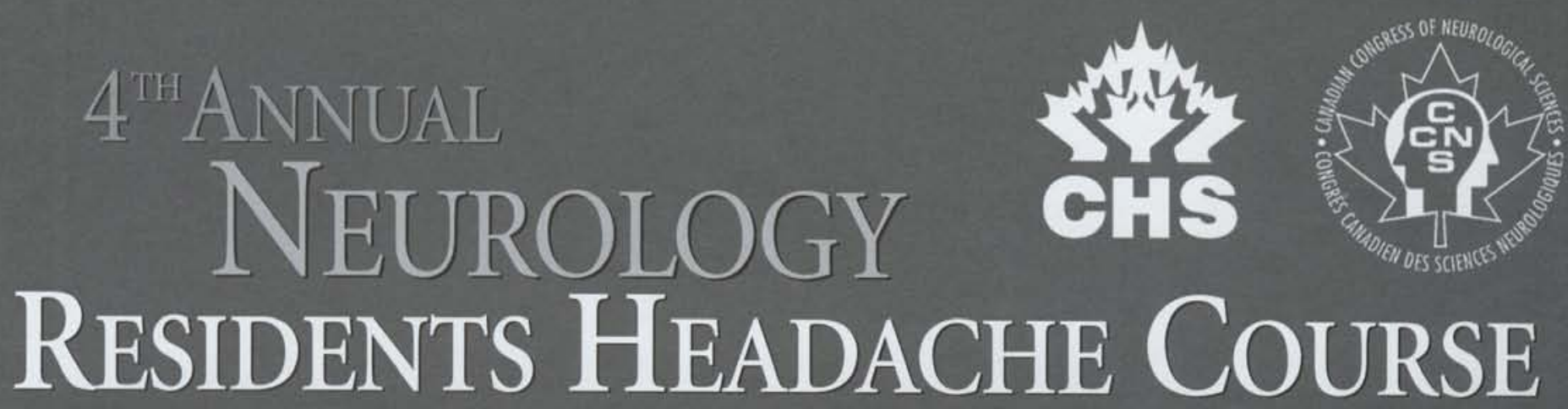

$\left.f i 1^{2}<\right)^{2}=$

10)

This two-day interactive course will be focused on primary and secondary headache disorders including major advances in imaging, pathophysiology, diagnosis and management.

Open to all senior neurology residents, PGY3 to PGY5.

Montreal Neurological Institute October 20-2I, 200I

\section{Co-chaired by:}

Dr. Allan Purdy, Halifax

Dr. Werner Becker, Calgary

Special guest faculty:

Dr. Peter Goadsby, National Hospital at Queen Square, London, UK

Dr. Fred Sheftell, New England Center for Headache, Stamford, Connecticut Dr. David Dodick, Mayo Clinic, Scottsdale, Arizona

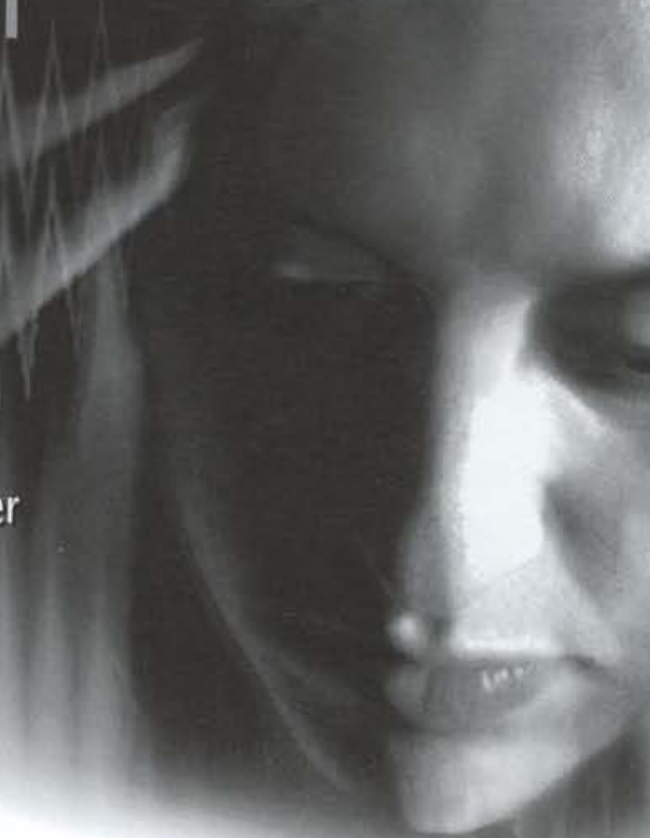

Supported by an unrestricted educational grant from 


\section{$4^{\text {TH }}$ ANNUAL \\ NEUROLOGY \\ RESIDENTS HEADACHE COURSE}

Friday October 19, 200I

19:30-22:00 Welcome Reception

\section{Saturday October 20, 200I}

07:00 Breakfast

07:30-08:00 Pretest

08:00-08:30 Headache Classification and

Epidemiology

08:30-08:40 Questions

08:40-09:25 Imaging Headache - State of the Art 2001

09:25-09:40 Questions

09:40-10:00 Coffee Break

10:00-10:45 Headache History Taking - Patient

Based

10:45-12:15 Case-Based Session (Migraine)

12:15-12:45 Resident Summaries of Case Discussions

12:45-13:45 Lunch

13:45-15:45 Chronic Daily Headache and Medication Induced Headache

15:45-16:00 Break

16:00-17:30 Case-Based Session (Secondary Headaches)

17:30-17:55 Resident Summaries of Case Discussions

\section{Sunday October 2I, $200 \mathrm{I}$}

08:00-08:20 Diagnosis/Investigation

08:20-08:30 Questions

08:30-09:15 Migraine Therapy - Acute and Preventative

09:15-09:35 Tension Type Headache Therapy

09:35-09:45 Questions

09:45-10:00 Break

10:00-10:40 Case-Based Session (Trigeminal Autonomic Cephalalgias)

10:40-11:00 Therapy of Trigeminal Autonomic Cephalalgia

I 1:00-1 I:30 Posttest

11:30-12:00 Burning Issues

12:00 Certificate Ceremony

\section{Notes:}

- This course will combine primary and secondary headaches in one year.

- We will emphasize imaging this time but this of course will include some neurobiology.

- The headache history will be new and could a case on video or a live patient.

- There will be more case based sessions, and feedback from the residents.

- There will be a pretest and a posttest again.
19:00 Reception and Dinner

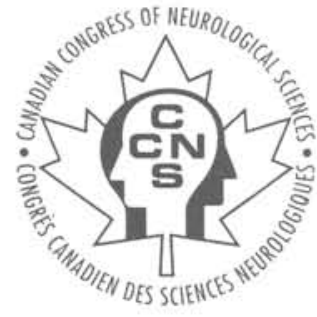

For more information please contact the Canadian Congress of Neurological Sciences Tel: (403) 229-9544; Fax: (403) 229-I66I; E-mail: brains@ccns.org 


\title{
25 Years Ago in the \\ Canadian Journal of Neurological Sciences
}

\author{
Genetic and Family Studies in Friedreich's Ataxia \\ E. Andermann, G.M. Remillard, C. Goyer, L. Blitzer, F. Andermann and A. Barbeau
}

SUMMARY: This study consists of two parts: 1. A detailed genetic analysis of 35 sibships in which 58 individuals were affected with Friedreich's ataxia; and 2. Clinical and laboratory examinations of parents and siblings, in an attempt at carrier detection and diagnosis of the preclinical state.

The increased parental consanguinity, the lack of affected individuals in other generations, and the lack of significance of extrinsic etiological variables, all suggested an autosomal recessive mode of inheritance, and this was confirmed by formal genetic analyses, employing several different methods.

Associated abnormalities in our series of 58 patients included cardiomyopathy $(51.7 \%)$, diabetes mellitus (19.0\%), optic atrophy $(5.2 \%)$, nerve deafness $(5.2 \%)$ and congenital malformations $(6.9 \%)$. The incidence of diabetes mellitus, congenital malformations, and epilepsy and/or febrile convulsions was elevated in first degree relatives of patients with Friedreich's ataxia.

Examinations in first degree relatives revealed an increased frequency of neurological and skeletal abnormalities (26.3\%), but no abnormalities on neuro-ophthalmological examination. Frequent EMG abnormalities were noted in parents $(56.3 \%)$, but not in siblings; and these could usually be attributed to extrinsic causes. There was an increased incidence of ECG abnormalities in both parents $(50.0 \%)$ and siblings $(25.0 \%)$ and some of these abnormalities may represent cardiomyopathy. An increased frequency of EEG abnormalities was also recorded in parents $(14.3 \%)$ and siblings $(27.2 \%)$, but these were not specific. None of these examinations resulted in a practicable method of carrier detection or preclinical diagnosis.

Since carrier detection is still not feasible, genetic counselling remains the only possible means of prevention of Friedreich's ataxia.

Can. J. Neurol. Sci. 1976;4:287

\section{Friedreich's Ataxia: PREliminary Results of SOME GENEALOGICAL RESEARCH}

A. Barbeau, M. Le Siege, G. Breton, R. Coallier and J.P. Bouchard

SUMMARY: A preliminary genealogical investigation of all the known ancestors from the year 1608 of four apparently unrelated French Canadian kindreds with Friedreich's ataxia reveals that the original ataxia gene in the province of Quebec was present within a core of no more than 10 families living in Quebec City in the mid-1600s.

Can. J. Neurol. Sci. 1976;4:303

\section{FRIEDREICH'S ATAXIA: OBSERVATIONS WITH Q AND G BANDING of Human CHROMOSOMES}

\author{
M. Cadotte, A. Barbeau and G. Breton
}

SUMMARY: No chromosomal anomaly was found in 15 cases of typical Friedreich's ataxia and three cases of atypical recessive ataxia studied with $\mathrm{Q}$ and $\mathrm{G}$ banding techniques. No difference between frequency of chromosomes gaps or breakages was noted amongst patients with Friedreich's ataxia and controls.

Can. J. Neurol. Sci. 1976;4:307 


\section{Now we can celebrate the}

\section{long-term benefits in the treatment of Alzheimer's disease}

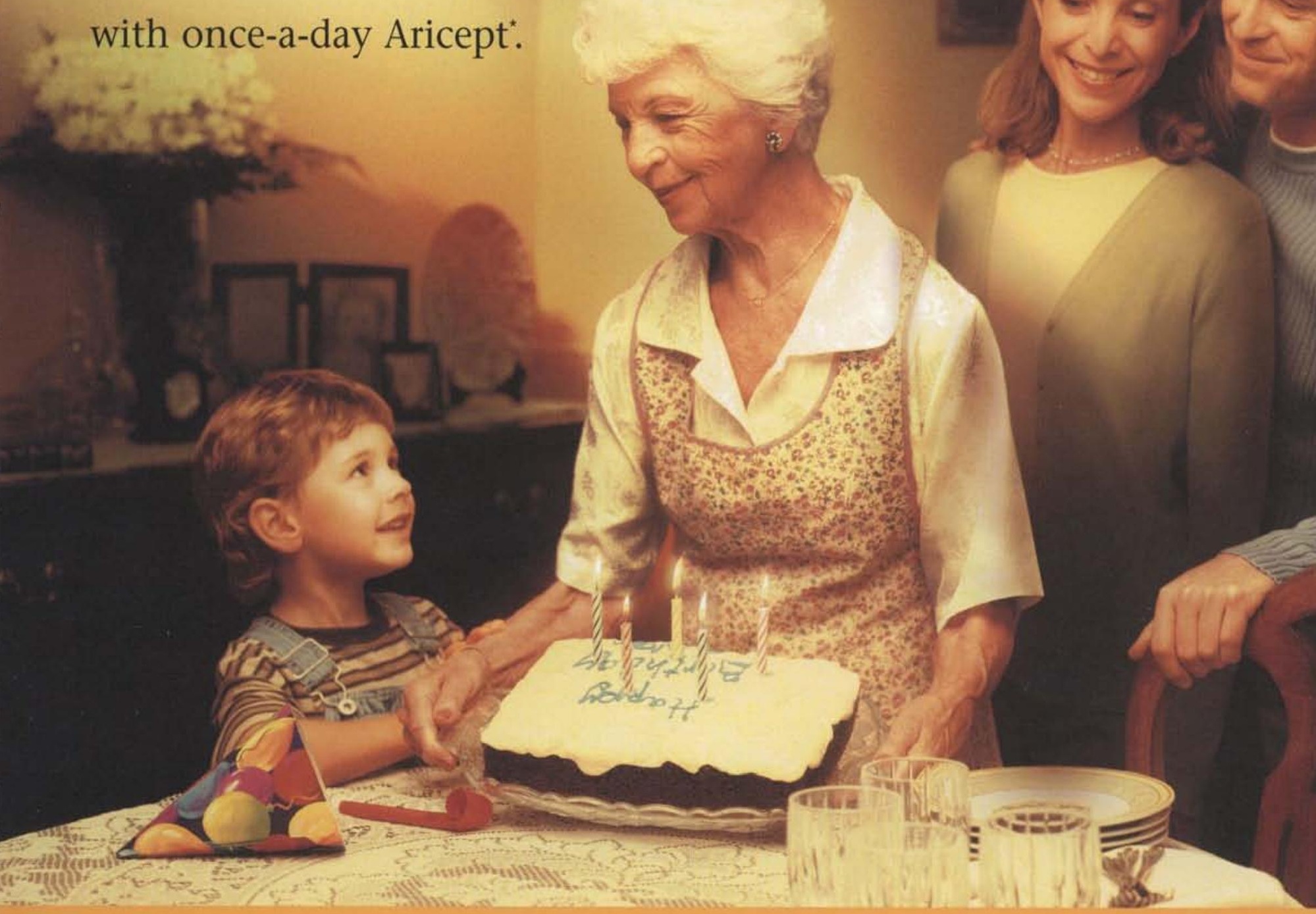

There's cause for celebration-because Aricept* has been shown to
result in improvement or stabilization in $80 \%$ of Alzheimer's disease patients over 6 months of treatment. ${ }^{*}$ And long-term data shows that Aricept $t^{*}$-treated patients continued to show treatment benefits up to 3 years on cognition and global functioning compared to data expected from untreated patients. ${ }^{25}$ What's more, Aricept* has demonstrated long-term safety and tolerability profiles.$^{2+}$ All of which means there's even more reason to make Aricept* your standard of care. ${ }^{3}$

Aricept" does not change the underlying course of the disease. Aricept* is indicated for the symptomatic treatment of patients with mild-to-moderate dementia of the Alzheimer's type.

$\uparrow$ With appropriate dose escalation $5 \mathrm{mg} /$ day dose, $10 \mathrm{mg} /$ day dose and placebo were shown to have comparable adverse events. Most common adverse clinical events with Aricept*: diarrhea, nausea insomnia, fatigue, vomiting, muscle cramps and anorexia. These events are usually mild and transient, resolving with continued Aricept ${ }^{*}$ treatment without need for dose modification.

\$In a 24-week, double-blind, placebo-controlled study, 473 mild-to-moderate AD patients weere andomized to recelve Aticent

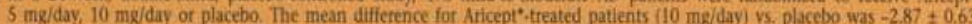

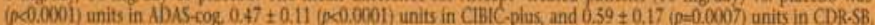

\$ In a 162 -week multicentre, open-label extension study, 579 patients who had previousily completed a andomized, doubleblind placebo-controlled study with Arcept" were treated with Aricept $5 \mathrm{mg}$ which could be increased to $10 \mathrm{mg}$ between weeks 6 and 24 as per cliniclan's judgement. At study endpoint, ADAS-cog deciined 15.57 points $(95 \%$ C C1,12, 19.2) is. the estimated decline of $6-12$ points per year in untreated potients

I in Saskatchewan, Quebec, Albetta, Manitoba and Ontario. Please see individual formularies for special, exceptional, and limited-use drug status. For more information on coverage criteria, please call 1-800-310-6141.
Now on several provincial formularies. ${ }^{1}$

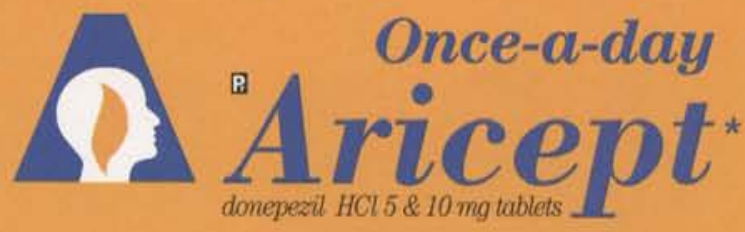

Hope for a brighter tomorrow

Product Monograph available upon request.

- TMEisai Co. Lud., Tokyo, Japan

Ptizer Canada Inc, licensee

02001

2001

Kirkland, Queber

Kirkland,
H9/ $2 \mathrm{MS}$

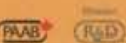





\section{EFFICACE CONTRE UN GRAND NOMBRE DE TYPES DE CRISES.}

- TOPAMAX est efficace contre les crises partielles initiales, les crises tonico-cloniques primaires généralisées et les crises associées au syndrome de Lennox-Gastaut ${ }^{1}$

- Des résultats souhaitables avec absence totale de crises chez $19 \%$ des adultes ${ }^{\dagger}$ et $22 \%$ des enfants ${ }^{\ddagger}$ atteints de crises partielles initiales ${ }^{2,3}$

\section{AUCUN SIGNE D'EFFETS SECONDAIRES CAPABLES DE MENACER LE PRONOSTIC VITAL.}

- Comme pour la plupart des antiépileptiques, les effets secondaires le plus fréquemment signalés relèvent du SNC et sont généralement légers à modérés et de nature passagère ${ }^{51}$

\section{IL EST POSSIBLE OUE LES PATIENTS ADULTES SUBISSENT UNE PERTE DE POIDS.}

- $73 \%(n=52)$ des patients ont subi une perte de poids de 5,97 lb en moyenne (Analyse provisoire. Durée moyenne de 60 jours)

- $96 \%$ des enfants traités dans le cadre des essais cliniques pendant au moins un an et ayant subi une perte de poids ont repris du poids au cours de la période d'exécution des essais" ${ }^{\prime \prime 1}$

\section{AUJOURD'HUI, IL Y A TOPAMAX.}

\section{MAINTENANT}

OFFERT EN CAPSULES

A SAUPQUDRER
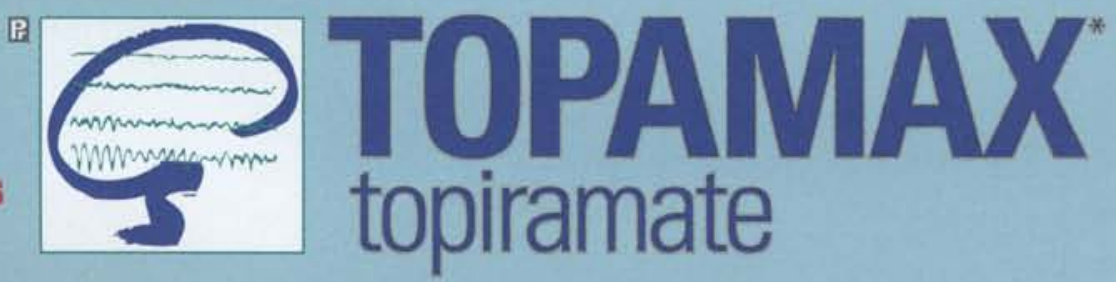

MAINTENANT

INDIDUE

CKEZ L'ENFANT

\section{POUR AIDER LES PATIENTS A MIEUX PROFITER DE LA VIE}

Comprimés et copsules à saupoudrer "TOPAMAX" (topiramate) : indiqués comme traitement adjuvant chez les patients (adultes et enfants ageés de deux ans ou plus) atteints d'épilepsie dont l'état n'est pas maitrisé de façon satisfaisante avec le traitement traditionnel. Les renseignements sur l'emploi du topiramate en monothérapie sont encore limités'.

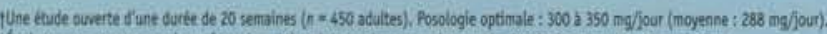
thide overte portant sur des erifants $(n=72)$ traits pendant au woirs 3 mols. Posologie noyenne : $10 \mathrm{mg} / \mathrm{kg} /$ jour.

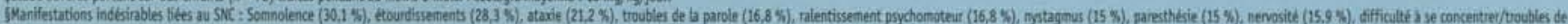

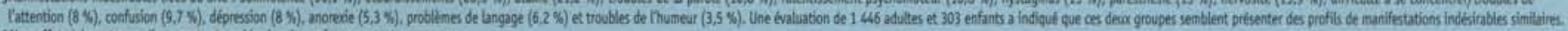

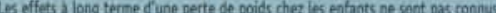

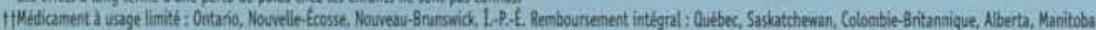

Vesillez vous reparter aux Rerseignements therapeutiques sur Toparax pour les details thírapeutiques complets.

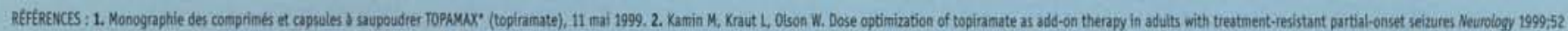
(Suppl 2):A525-526. 3. Glauser TA, Etterman R, Wyltie E et al. Open Label topiramate in paediatric partial epilepsy Epilepsio 1997:38 (SuppL. 3):94, 4. Rosenfeed WE et af. Topiramate and contomitant weight loss. Epilepsia 1997:38 (Suppl 8):98. 


\section{7th Meeting of the}

\section{Canadian Congress of Neurological Sciences}

\section{VanCOUVER, British COLUMBIA}

\section{with the Australian Association of Neurologists}
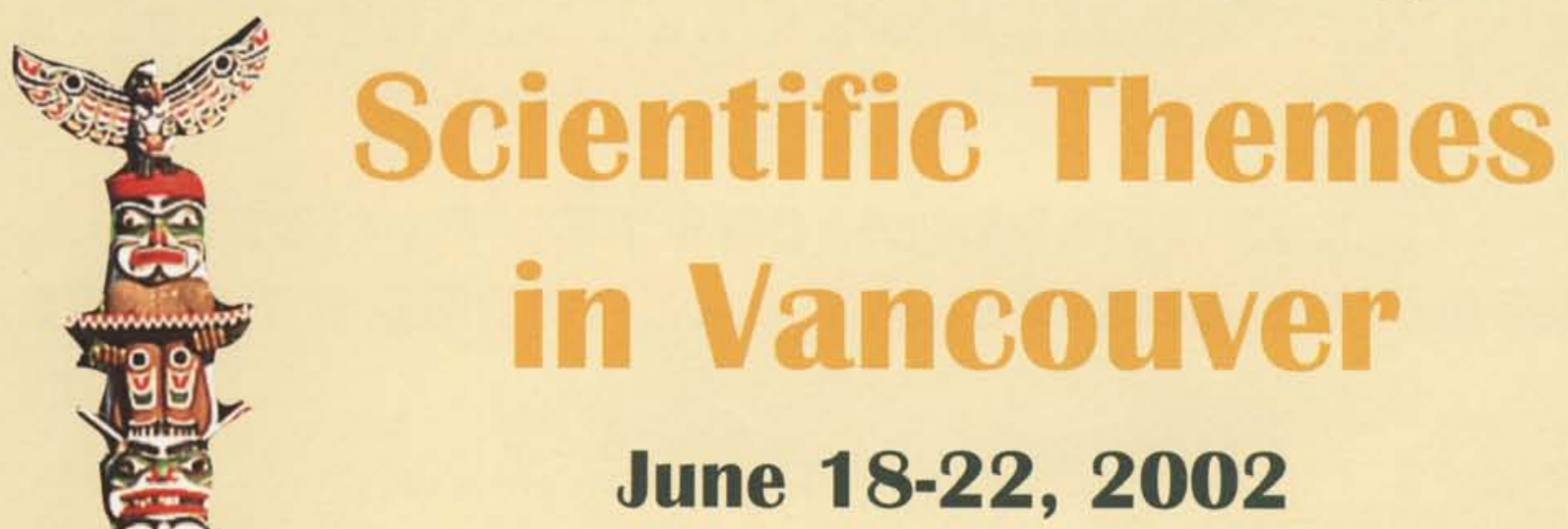

June 18-22, 2002

\section{Tentative Scientific Program}

TUESDAY JUNE 18, 2002

Pre-Congress Courses

Neurobiology Review Course

ALS Strategies for Quality of Life and

Quality of Care

Movement Disorder Video Session

Epilepsy Video Session

WEDNESDAY JUNE 19, 2002

\section{Course Day}

Spinal Surgery Course

Evidence Based Neurology

CSCN EMG

Update on Radiosurgery

Introduction of Design and Analysis of

Clinical Research

\section{CSCN EEG}

Imaging in Neurocritical Care

Welcome Reception
THuRSDAY JUnE 20, 2002

\section{Plenary Session I}

Platform Sessions

Lunch, Poster Viewing, Exhibit viewing Interactive/CPC Neurology/Neurosurgery

Wine and cheese/Poster viewing

FridAY JUNE 21, 2002

Meet the Expert Breakfast:

Neurosurgery

Plenary Session II

Platform Sessions

Lunch, Poster Viewing, Exhibit viewing

CLAE/CEC Epilepsy

Update on peripheral nerve surgery

Neurosonology or Ultrasound in

Neurology/Neurosurgery

Neuroscience Challenge and Social

Night

SATURDAY JUNE 22, 2002

Plenary Session III

Child Neurology Day

Stroke Course: Neurovascular

Endovascular Surgery

MS Course 


\section{Rebifi. Efficacité dépendante de la dose dans}
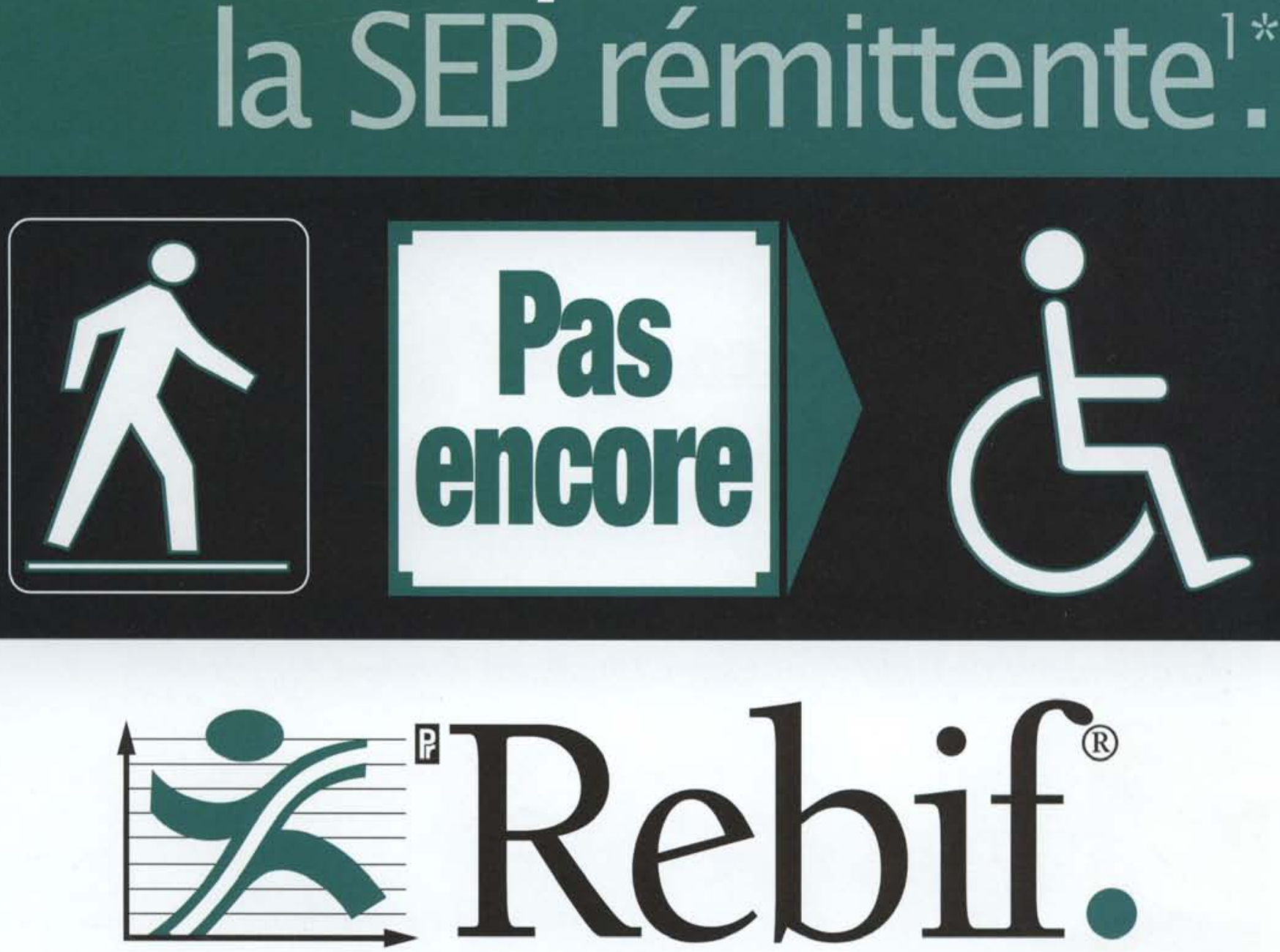

I $n \mathrm{t}$ e $\mathrm{r}$ f é $\mathrm{r}$ o $\mathrm{n}$ b ê $\mathrm{t}$ a -1 a

prêt à l'emploi

préremplie

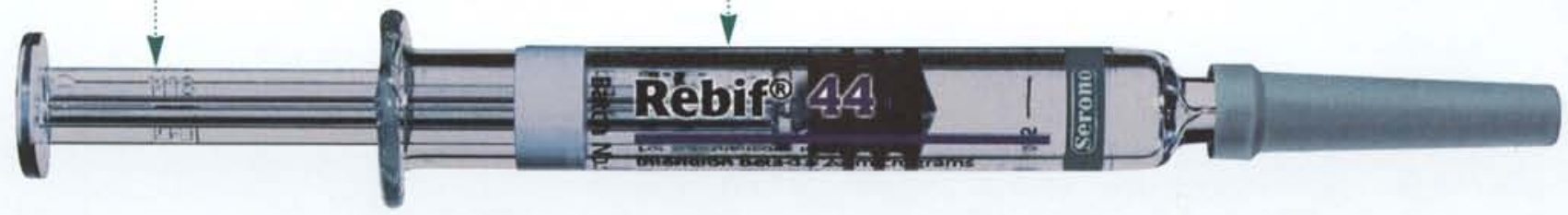

Les effets secondaires les plus fréquemment observés sont les réactions au point d'injection et les symptômes pseudo-grippaux (asthénie, pyrexie, frissons, arthralgie, myalgie et céphalées). Leur fréquence et leur intensité tend à diminuer avec la poursuite du traitement. Veuillez consulter la monographie du produit pour les renseignements posologiques complets. Les données portant sur l'innocuité et l'efficacité proviennent d'observations sur 2 ans seulement.

* Rebif" est indiqué pour le traitement de la sclérose en plaques rémittente chez des patients dont la cote EDSS se situe entre 0 et 5,0, afin de réduire le nombre et la gravité des poussées cliniques, de ralentir la progression de l'invalidité physique, et de réduire les besoins de corticothérapie et le nombre de séjours à l'hôpital pour le traitement de la sclérose en plaques.

\section{RÉFÉRENCE :}

Croupe d'étude PRISMS (Prevention of Relapses and Disability by Interferon B-la Subcutaneously in Multiple Sclerosis), 1998. Randomised double-blind placebo-controlled study of Interferon B-1a in relapsing/remitting multiple sclerosis. Lancet, 352:1498-1504

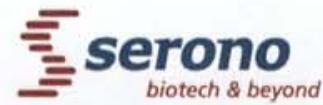




\section{Introducing...}

New

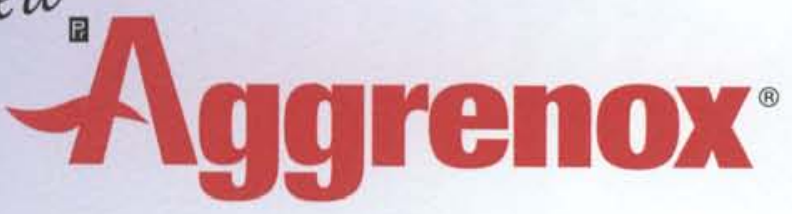

Prevented twice as many strokes

vs. $\mathbf{A S A}^{2,3,4^{*}}$

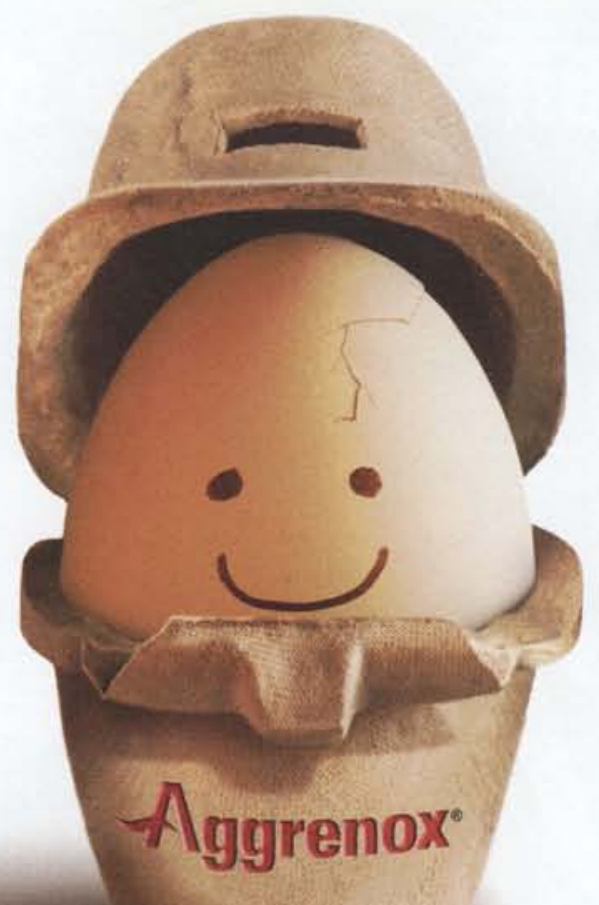

\section{New American College of Chest Physician Stroke Guidelines state':}

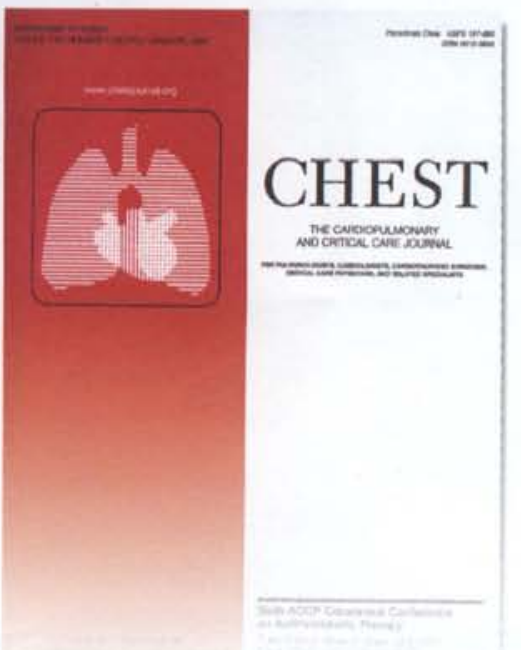

"Aggrenox is more effective than ASA alone for the
prevention of [secondary] stroke" (grade 1A evidence)

\section{Consider switching your ASA patients to Aggrenox:}

- $22.1 \%$ additional stroke protection over ASA $(p=0.008)^{3+5}$

- $36.8 \%$ additional stroke protection over placebo $(p<0.001)^{3}$

- Proven safety and tolerability profile ${ }^{3+t}$ (Most common adverse events vs. ASA alone and vs. placebo: headache $39.2 \%, 33.8 \%, 32.9 \%$; nausea $16.0 \%, 12.7 \%, 14.1 \%$.)

- One capsule B.I.D. ${ }^{3}$

The overall discontinuation rate for Aggrenox was $27.8 \%, 23.2 \%$ for ASA and $23.7 \%$ for placebo. ${ }^{3}$

Aggrenox is indicated for the prevention of stroke in patients who have had a previous stroke or transient ischemic attack (TIA). ${ }^{3}$

Aggrenox is contraindicated in patients with hypersensitivity to dipyridamole, ASA, or any of the other product components. Due to the ASA content, Aggrenox is also contraindicated in patients with known allergy to nonsteroidal anti-inflammatory drug products and in patients with the syndrome of asthma, thinitis and nasal polyps. ${ }^{3}$ Due to the ASA component, Aggrenox should be avoided in patients with severe hepatic insufficiency or severe renal failure, used with caution in patients with inherited/acquired bleeding disorders or who consume three or more alcoholic drinks every day, and avoided in patients with a history of active peptic ulcer disease. Aggrenox should not be used in pediatric patients or during the third trimester of pregnancy. ${ }^{3}$

Aggrenox has a vasodilatory effect and should be used with caution in patients with severe coronary artery disease (e.g., unstable angina or recently sustained myocardial infarction).

* For every 1,000 patients treated for two years, Aggrenox prevented 58 strokes vs. only 29 for ASA, compared to placebo. ${ }^{23}$

$\dagger$ Percentage of patients experiencing a stroke within two years: Aggrenox 9.5\%, ASA $12.5 \%$, placebo $15.2 \%{ }^{3}$

$\S$ Randomised, double-blind, placebo-controlled trial, 6602 patients with history of TIA or ischemic stroke, mean age 66.7 years, $58 \%$ male, $42 \%$ female. ${ }^{2}$

†† When headache occurred, it was particularly evident in the first month of therapy. $8.9 \%$ of patients discontinued due to headache, $66 \%$ of these discontinued within the first month.

Full Product Monogaph is available upon request.

-Aggrenox is a registered trademark of Boehringer Ingelheim (Canada) Ltd.

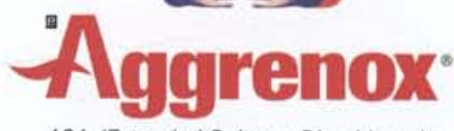

ASA/Extended Release Dipyridamole

Helping to maximize stroke protection 